\title{
O SISTEMA NERVOSO ESPIRITUAL: REFLEXÓES SOBRE UM POSSÍVEL CABO MAGNÉTICO PROJETADO PARA COMUNICAÇÃO ESPIRITUAL ${ }^{1}$
}

\author{
THE SPIRITUAL NERVOUS SYSTEM: REFLECTIONS \\ ON A MAGNETIC CORD DESIGNED FOR SPIRIT COMMUNICATION
}

Jeremy Stolow ${ }^{2}$

Em 1853 houve um crescimento vertiginoso do movimento espiritualista moderno. Andrew Jackson Davis, uma das principais figuras desse movimento, compilou um conjunto de instruçôes para a organização de séances. Seu principal argumento era de que o triunfo na comunicaçáo com o mundo espiritual dependia da presença de um balanço adequado de elementos positivos e negativos. Para esse fim, os frequentadores de séances foram instruídos a formar um "círculo harmônico"; aqueles cujo temperamento negativo foi sinalizado foram colocados em assentos alternados com aqueles indivíduos de temperamento positivo ${ }^{3}$. O balanço de forças necessário para comunicação com o mundo espiritual poderia ser aprimorado ainda com a preparação de condiçốes vantajosas no ambiente. Os participantes eram levados a se encontrar em salas escuras, "longe de barulhos ou interrupçóes, para que pudessem se concentrar no objeto para o qual haviam se encontrado sem

1 Traduzido por Fernanda Brazil Kettes e Manoela Alcaria Silveira, sob a supervisão e a revisão de tradução da Prof. ${ }^{a}$ Dr. ${ }^{a}$ Elizamari R. Becker (IL/UFRGS). Revisão técnica por Barbara Jungbeck e Rodrigo Toniol.

2 Jeremy Stolow é professor adjunto do Departamento de Estudos da Comunicação da Universidade Concórdia, Montréal, Canadá. E-mail: jeremy.stolow@concordia.ca.

3 Davis, 1853. O cabo magnético de Davis é discutido brevemente em Catherine L. (2007). Estou em débito com Albanese por chamar atenção para o cabo de Davis, apesar de, como eu espero que fique claro nas páginas a seguir, minha própria discussão elabora um conjunto diferente de consideraçóes. 
serem desvirtuados por agentes externos" (Davis, 1853, p. 164). Por fim e principalmente, Davis sugeriu que os frequentadores de séances deveriam:

Fazer um cabo magnético para si próprios... Pegar cinco metros de uma corda de três quartos de polegada, cobrir essa corda com seda ou veludo e enrolar em torno dessa corda, paralelos um ao outro, dois fios: um de metal e outro de prata ou cobre. Deixar os fios a uma polegada e meia de distância um do outro e deixar um quarto de polegada de distância entre cada volta de cada fio $^{4}$. (Davis, 1853 , p. 165)

Os participantes sentados foram instruídos a se reunirem em volta da mesa segurando seus cabos magnéticos no colo para estabelecerem "um equilíbrio de eletricidade vital e de magnetismo vital por todo o círculo" (Davis, 1853, p. 166). Uma vez que o circuito estivesse completo, Davis explica: "Aqueles que forem constitutivamente mais suscetíveis à influência espiritual de emoçóes sentirão as mãos latejarem e por fim, em função da repetição de experimentos, tornar-se-ão clarividentes" (Davis, 1853, p. 166). Mas mesmo após esses sinais iniciais de contato com o mundo sobrenatural, os participantes eram aconselhados a continuar segurando seus cabos por, pelo menos, mais uma hora, para só então deixá-los de lado e reconstituir o círculo segurando as máos uns dos outros. Nesse ponto, o cabo magnético terá servido ao seu propósito. Tendo-se estabelecido um círculo humano realmente harmonioso, "[...] os participantes podem ficar seguros de que espíritos guardióes e amigáveis estarão presentes, vindo até a sala pessoalmente em alguns momentos." (Davis, 1853, p. 168).

Os registros históricos não confirmam se os leitores de Davis realmente levaram adiante suas instruçóes para construírem seus próprios cabos magnéticos e incorporá-los em suas atividades de séance. Espiritualistas preocuparam-se mais com o conteúdo revelador das mensagens provenientes

${ }^{4}$ Davis revisou essas instruçóes cerca de trinta anos depois em The Present Age and Inner Life: Ancient and Modern Spirit Mysteries Classified and Explained (Boston: Colby \& Rich, 1886), p. 101-03. 
dos contatos com o mundo espiritual e menos com o equipamento usado para estabelecer esse contato ${ }^{5}$. Mas o texto de Davis oferece uma descriçáo detalhada dos instrumentos e das técnicas que ao menos alguns espiritualistas devem ter considerado úteis para contatar o mundo espiritual. Sua descrição do cabo magnético é um exemplo do que se pode chamar de tecnologia dos espiritualistas para comunicação sobrenatural: um instrumento cuja função era gerar um circuito que liga mente, corpo, espaços físicos e forças imateriais em uma rede de pensamento, discurso e açáo. Como um meio de transdução de diferentes forças e energias nessa rede de circuitos, o cabo parece ter sido desenvolvido para realizar tarefas variadas como fazer os participantes de séance sentirem as mãos latejando, facilitar manifestaçôes visuais ou auditivas e até mesmo fornecer aos espíritos acesso direto às mentes e aos corpos dos vivos, para que aqueles possam falar e agir por meio desses.

5 Isso não é para desvalorizar a grande dedicação entre os espiritualistas a uma forma de positivismo científico, que sustentava que a veracidade de experiências paranormais e sobrenaturais durante os rituais das sessóes espíritas poderia ser estabelecida através de observação controlada. A esse respeito, é importante frisar os esforços altamente divulgados de um número de cientistas notáveis - tanto os simpatizantes quanto os céticos dos princípios básicos do Espiritualismo - para conduzir experimentos durante as sessôes espíritas, tratando a câmara das sessóes como um tipo de laboratório de observaçáo controlada e análise de evidências. Entre os muitos cientistas que entraram nas câmaras e documentaram seus achados estavam Robert Hare, Michael Faraday, Alfred Russell Wallace, Edmund Carpenter, Cromwell Varley, e Oliver Lodge; ver Peter Lamont (2004, p. 897-920); Richard J. Noakes (1999, p. 421-59); Jon Palfreman (1979, p. 210-23); Peter Pels (2003, p. 241-71); Elisabeth Wadge (2000, p. 24-42). 
Figura 1 - The Magic Rope.

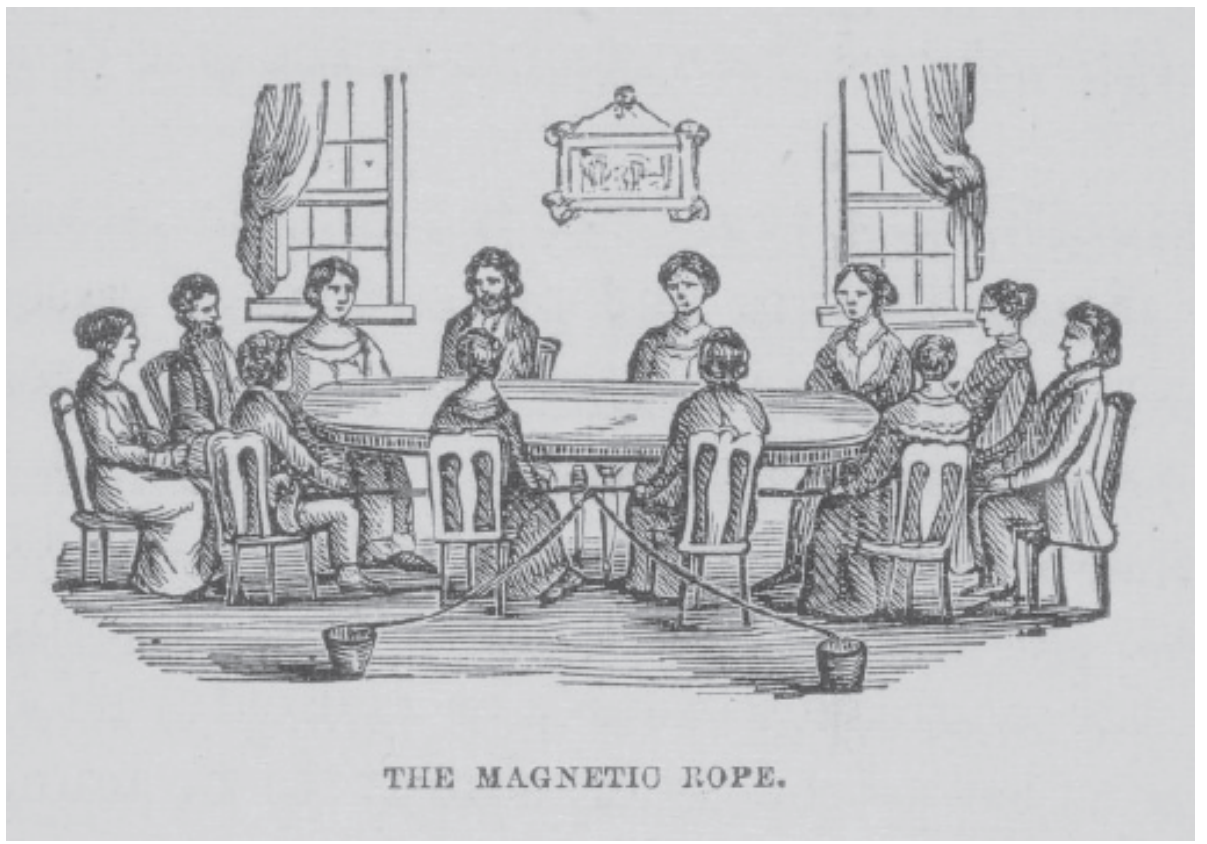

Fonte: Andrew Jackson Davis, The Present Age and Inner Life; Ancient and Modern Spirit Mysteries Classified and Explained (Boston: Colby \& Rich, 1886), p. 101.

De todas essas maneiras, o cabo de Davis mostra um pouco como os espiritualistas contribuíram para a "tecnologização" (ou deveria-se dizer “retecnologização"?) da ordem sobrenatural. Em torno do cabo, uma pessoa encontra náo somente tiras de seda, cobre e ferro, mas também profundas suposiçôes ontológicas e cosmológicas sobre a sobrevivência da alma após a morte, sobre a constituição fisiológica das almas simpáticas capazes de comunicarem-se com o mundo espiritual e a receptividade dos corpos humanos, objetos materiais e entidades imateriais para um conjunto de princípios operativos comuns. Princípios esses modelados na física da condutividade e indução eletromagnéticas. Por poder ser dobrado em um círculo e, portanto, englobar objetos dentro de seu "circuito", o cabo 
magnético de Davis faz companhia a outros fenômenos ganhando visibilidade novamente nas discussóes públicas do século XIX. Essas discussôes incluíam cabos de telégrafo, linhas ferroviárias e os gânglios e filamentos de sistemas nervosos corporais. No contexto em expansão de corpos de conhecimento e experimentos práticos envolvendo particularmente a eletricidade, o espiritualismo do século XIX traz uma visão de conexão do corpo, da ordem social, do mundo natural e do desconhecido, por meio de um elo de objetos organizados (cabos magnéticos, cadeiras, mesas e salas escuras), nervos sensíveis, vibraçôes elétricas e fios finos de força espiritual. Brincando com a etimologia da palavra nervoso, derivada de neuron, palavra grega para tendáo ou para corda, as próximas páginas oferecem explicaçôes sobre o que chamarei de "sistema nervoso espiritual", no qual o instrumento de Davis foi embutido: uma explicaçáo que, espero, evoque mais reflexôes sobre o espaço semântico compartilhado em que religiáo e tecnologia sáo nomeados como entidades distintas.

É claro que espiritualistas não foram os primeiros "teólogos da eletricidade", termo que poderia ser aplicado a inúmeros grupos, olhando para trás, pelo menos até o século XVIII, quando não era raro que se comparassem as maravilhas da eletricidade aos milagres bíblicos e, com efeito, descrevê-las como um meio de manifestaçáo da vontade divina, presente em fenômenos naturais como relâmpagos durante uma tempestade ou nas convulsóes dos corpos protestantes passando por renascimento espiritual ${ }^{6}$. Além disso, como apontado por Bret Carroll, espiritualistas haviam recorrido a tradiçóes filosóficas e religiosas ainda mais antigas em se tratando de seu uso da figura do círculo - um símbolo remoto de ordem e de harmonia em suas descriçóes do cosmos (no qual tanto o mundo dos espíritos como o mundo físico estão alinhados em uma série de esferas concêntricas), no modo como organizavam suas atividades ritualísticas (sentando-se em volta de mesas redondas), e em suas discussōes sobre harmonia social e virtude republicana (nas quais círculos apareciam como metáforas da intimidade

${ }^{6}$ Ver, por exemplo, Ernst Benz (1989); Paola Bertucci, (2006, p. 341-62). 
familiar, irmandade religiosa e pertencimento nacional) ${ }^{7}$. Mas para espiritualistas norte-americanos do meio do século, passou a ser possível descrever os poderes do círculo fazendo referência à linguagem e ao comportamento de um circuito elétrico. Seu uso liberal do léxico de circuitos elétricos marca, portanto, grande comprometimento por parte dos espiritualistas como Davis com os procedimentos e com os discursos legitimados da ciência, da medicina e da engenharia modernas. Ainda mais fundamentalmente, talvez, isso marca sua conceitualização compartilhada da comunicação em si como o resultado do recebimento bem sucedido de um sinal localizado dentro de um sistema interligado de forças gerativas, meio transmissor, pontos terminais e loops de feedback. Como será abordado, a lógica do sinal está na raiz do que se presumiu que tornaria o dispositivo de Davis, o cabo magnético, eficaz no contexto da prática de séance. Mais genericamente, o trabalho do circuito de processamento do sinal forneceu uma base discursiva chave para a articulação das ideias espiritualistas sobre comunicação com espíritos, graças a um consenso sobre a natureza da transmissão elétrica que se formou em torno da comunidade espiritualista, em cenas rapidamente evoluídas de experimento científico, engenharia industrial, pesquisa médica e na representação dos conhecimentos especializados no campo vasto da cultura pública transatlântica.

O cabo magnético de Davis merece atenção por sua localização no espaço intelectual, cultural e comercial, em algum lugar no limite entre ciência "apropriada" e "amadora”. Esse era o espaço para circulação de instrumentos e de procedimentos técnicos frequentemente (mas não sempre) inicialmente desenvolvidos para pesquisa científica, mas não rotineiramente reproduzidos para fins pedagógicos, de entretenimento ou de consumo doméstico. Esse era também o espaço para a circulação e hibridização de discursos e de práticas observacionais científicas e reuniáo de informaçóes em um grupo de interlocutores que hoje em dia apressadamente dividiríamos entre profissionais e amadores. $\mathrm{Na}$ época de Davis, essa distinção era feita somente no sentido

7 Ver Bret E. Carroll (1997, p. 61-65, p. 129-40). 
de discernir aqueles cientistas com educação formal e os que não possuíam educação formal. Nesse sentido vale a pena demorar-se no fato de que não somente a funçáo operacional do cabo magnético de Davis relativamente avançada (segure-se e concentre-se), como também sua construção, era fácil, necessitando apenas de coisas que os leitores de classe média de Davis teriam disponíveis em casa. Por diminuir os requisitos necessários para participação em um ritual séance, pode-se dizer que o cabo oferece uma maneira de democratizar os termos de acesso aos poderes transcendentes. As instruçôes de Davis para a construção e para o uso de um cabo magnético ecoam o que era de fato um tema recorrente nos escritos espiritualistas ao longo do século XIX: que náo deveria haver nenhum portão institucionalmente circunscrito para o mundo espiritual, certamente não aqueles que conferiam monopólio de conhecimento a padres ou outros tipos de especialistas em rituais (não obstante, os médiuns célebres, assistentes de palco, editorialistas e outros que tinham seus próprios interesses simbólicos e econômicos para proteger). Na companhia de muitos outros espiritualistas, Davis nunca se cansou de professar que o mundo espiritual estava em princípio acessível a todos. Isso fica muito claro em sua argumentaçáo de que qualquer círculo adequadamente formado teria potencial para o sucesso e que ninguém pode determinar antecipadamente qual membro do círculo possui a constituição suficientemente "simpática" para ser o primeiro a registrar um sinal do mundo dos espíritos por meio das vibraçôes elétricas do cabo (Davis, 1893, p. 168). A democracia pertencente à organização e à performance de um ritual séance também pertencia ao trabalho intelectual de espiritualistas como um todo no meio da cultura pública energeticamente consumida por notícias das mais recentes descobertas científicas e pelas maravilhas da engenharia moderna. Tendo sido escolhidos pelo mundo espiritual para fornecer novos conhecimentos sobre o corpo, a mente, a alma, a ordem natural e o cosmos, escritores como Davis trabalharam lado a lado, e por vezes um contra o outro no que estava apenas começando a ser claramente reconhecido como uma forma profissional de ciência, engenharia e medicina. 
Apesar da inquietaçáo de muitos historiadores, ainda é lamentavelmente comum encontrar a imagem banalizada do século XIX como um período marcado por uma grande lacuna entre ciência e religiáo, com o crescimento de uma comunidade científica cada vez mais especializada e fundamentalmente "secular" organizada em corpos profissionais que delimitavam critérios para pesar evidências, endossar teorias e medir perícia ${ }^{8}$. Mas espiritualistas intelectuais como Davis não se enquadram no molde esperado dos "homens de ciência" que supostamente perderam a fé ao longo do caminho da pesquisa científica sem restriçóes. Nem tampouco seus escritos poderiam ser relegados simplesmente como parte da cultura popular, um domínio por vezes depreciativamente descrito em termos de sua ignorância e distorção da discussão científica "real" que se dá em outro lugar. Tais consideraçôes não só exageram a passividade dos escritores não especializados como meros condutores de conhecimento científico, mas falham em chegar à raiz da ciência popular como uma arena para discussão pública e combate prático'. Prestar atenção a essa arena requer, em primeira instância, que se resista a toda tentaçáo de tratar o cabo magnético de Davis como uma invençáo idiossincrática de um autodidata marginal (se não um religioso maluco), assim como não devemos

${ }^{8}$ Algumas das críticas mais incisivas sobre a "tese do conflito" entre ciência e religião têm sido expressas por historiadores da ciência vitoriana, que apontaram quantos elementos narrativos compunham a chamada "guerra" travada por mentes científicas questionadoras sobre as superstições religiosas que estavam enraizadas nas aspirações dos iconoclastas profanos, ansiosos por conseguir a "ciência moderna" em sua luta pelo domínio sobre a recém-criada esfera da educação estatal no final do século XIX; ver Frank M. Turner (1978, p. 356-76); John Hedley Brooke (1991); Thomas Dixon, Geoffrey Cantor e Stephen Pumfrey (2010).

${ }^{9}$ Estudos exemplares de ciência popular no século XIX incluem Roger Cooter (1984); Robert Darnton (1968); Aileen Fyfe (2004); Craig James Hazen (2000). Sobre a história da relação entre os engenheiros eletricistas profissionais e a cultura popular estadunidense do final do século XIX, ver Carolyn Marvin (1988), particularmente o capítulo 1. Para um tratamento extensivo da negligência para com a ciência popular como um tópico sério de investigação, ver Roger Cooter e Stephen Pumfrey (1994, p. 237-67). 
nos permitir agarrar-nos às consideraçóes sobre o sistema nervoso espiritual de maneira suspensa às margens da cultura tecnológica do século XIX. Ao contrário, deve-se percebê-lo como um instrumento que tanto imitava como competia com todos os tipos de aparatos tecnológicos necessários em outras situações para atividades científicas de medição e observação, ou para a construção e coordenação técnica de infraestruturas de comunicação mediadas eletricamente. O cabo magnético de Davis convida-nos para o coração da modernidade transatlântica.

\section{TECNOCIÊNCIA E A IMAGINAÇÃO ESPIRITUALISTA: O TELÉGRAFO ESPIRITUAL}

Como um movimento religioso, uma moda cultural e um objeto de controvérsia pública, o espiritualismo norte-americano floresceu no terceiro quarto do século XIX, um período de reestruturação social e de revolução tecnológica nos domínios da comunicação, transporte, produção de conhecimento e da formação dos hábitos do dia-a-dia entre as populações em constante urbanização e industrialização ${ }^{10}$. Muitas das ideias impulsionadas por espiritualistas a respeito da sobrevivência da alma após a morte e a respeito dos meios pelos quais os espíritos se manifestam podem, claro, ser rastreados por uma história muito mais longa de especulação metafísica e condução de rituais, chegando até às fundações da república americana, se não antes — nas profundezas das tradiçóes da Europa antiga de Hermetismo, neoplatonismo e das artes ocultas, como documentado recentemente por Catherine Albanese em sua magistral história sobre a tradução metafísica americana, A Republic of Mind and Spirit. É possível admitir que falar diretamente com os mortos é um negócio endêmico para muitas sociedades ao longo da história e que o espiritualismo norte-americano do século XIX constituiu uma variante local do que era certamente um desejo cultural

${ }^{10}$ As histórias essenciais do Espiritualismo do século XIX no mundo anglófono incluem Ann Braude (1989); Robert S. Cox (2003); Molly McGarry (2008). 
muito mais universal de comunicar-se com os desencarnados ou de receber conhecimentos e dádivas dos mortos. Mas a proeminência do espiritualismo e seu notável alcance geográfico é apenas atribuível ao solo fértil de pesquisa sensacionalista, espanto popular e fabricação internacional de notícias que alimentava a cultura pública emergente da modernidade transatlântica da metade do século XIX. Pela mesma razáo, quando espiritualistas exploraram as possibilidades de existência humana após a morte, eles frequentemente o faziam juntamente com as linhas de desenvolvimento industrial e de pesquisa científica de sua época. Nessa medida, o movimento refletia uma revolução cinética muito maior que estava colocando novas prioridades em movimento, transformação e progresso nas facetas civil, cultural e social na era Jacksoniana ${ }^{11}$. Não havia essa ênfase em mobilidade e conectividade mais evidente em outros campos do que nas apropriaçóes espiritualistas da ciência tecnológica do século XIX, a começar pelo telégrafo eletromagnético $^{12}$. De fato, o telégrafo funcionava no imaginário espiritualista como uma metonímia para uma onda muito maior de novas tecnologias e arranjos institucionais dos quais eles eram testemunhas nas fábricas, rotas de transporte, salas de aula, espetáculos públicos, casas de máquina e escritórios aparecendo em volta deles. ${ }^{13}$

Devo dizer mais sobre a figura do telégrafo em particular nos discursos espiritualistas. Mas, primeiro, algumas palavras serão a respeito da confiança de escritores espiritualistas em metáforas e argumentos causais emprestados

${ }^{11}$ O termo revolução cinética é emprestado da discussão de Catherine Albanese do movimento transcendentalista estadunidense da metade do século, que incluía figuras como Ralph Waldo Emerson; ver Albanese, (1975, p. 319-40). Para a aplicabilidade da noção de "revolução cinética” para o Espiritualismo estadunidense, ver Carroll, Spiritualism, p. 62-64.

12 Ver Jeremy Stolow (2008, p. 668-86). Eu dificilmente sou o primeiro a apontar a relação íntima entre Espiritualismo e telegrafia; ver também Albanese, Republic of Mind and Spirit, p. 225-27; Braude, Radical Spirits, p. 4-5, p. 23-24; Jeffrey Sconce (2000, p. 21-37); Werner Sollors, (1983, p. 992).

13 Sobre as apropriaçóes espiritualistas das tecnologias do seu tempo, ver Stolow, Salvation, p. 668-86; Steven Connor (1999, p. 203-25); Sheri Weinstein (2004, p. 124-40). 
da ciência e da indústria. É crucial situar esses textos no contexto histórico de um processo de "purificação" até hoje incompleto do discurso científico e da prática técnica, sob pena de terminarmos descaracterizando a ciência tecnológica do século XIX com recursos de distinçôes e definiçōes mais contemporâneas ${ }^{14}$. De fato, o século XIX marca um período no qual o negócio da ciência moveu-se pela primeira vez das mãos dos amadores aristocratas para as mãos do quadro de "cientistas" cada vez mais profissionais: termo cunhado em 1833 por William Whewell (1794-1866) que no meio do século começou a referir-se àqueles que trabalhavam no ambiente controlado de laboratórios e cujas descobertas eram objeto de investigação consentida de pares versados em campos cada vez mais especializados de conhecimento científico ${ }^{15}$. Esse processo histórico de purificação intelectual e institucional ajudou a discernir uma área emergente da ciência de um conjunto de atividades populares, divertidas e lucrativas e um conjunto de estruturas interpretativas que poderiam então ser rejeitadas como "não científicas".

Mas nesse mesmo tempo, a cultura pública burguesa transatlântica estava sendo reformulada por meio de crescimento paralelo de interesse em conhecimento científico e informação circulando pelas mídias locais, nacionais e internacionais, incluindo jornais, almanaques, panfletos e livros cada vez mais baratos nos quais jornalistas, políticos, teólogos e outras figuras

${ }^{14}$ Meu uso do termo purificação vale-se da famosa descrição de Bruno Latour do lugar do conhecimento científico dentro do que ele chama de "A Constituição Moderna”, um esforço histórico para atingir o objetivo (impossível e, portanto, sempre paradoxal) de distinguir natureza e cultura como duas zonas distintas ontologicamente, e, assim, assegurar à ciência moderna seu prestígio como objetivo e valor neutro; ver Latour (1993, p. 10-48).

${ }^{15}$ Ver George H. Daniels (1976, p. 63-78). Sobre a morte da filosofia natural e a invenção da ciência moderna, ver Simon Schaffer, (1986, p. 387-420). Sobre a demanda crescente, ao longo do século XIX, para reorganizar o conhecimento e a prática médicos através da especializaçáo profissional (não menos importante no domínio da neurologia, que toma forma como um ramo institucionalmente distinto de prática médica apenas no terço final do século), ver George Weisz (2003, 536-74). 
públicas comentavam extensivamente sobre novas descobertas astronômicas, geológicas e médicas, novas façanhas da engenharia e outras maravilhas da ciência moderna ${ }^{16}$. No tempo de Davis, a ciência no Mundo Novo - e especialmente a ciência da eletricidade - já havia tomado forma por um longo histórico de comentário público, mercantilização e domesticação, por meio de circulação transatlântica não só de textos científicos, mas também de instrumentos e dispositivos cada vez mais baratos e formas de demonstraçáo pública que habitava entre os mundos do experimento formal, pedagogia, entretenimento e empreendimento comercial. O exemplo mais famoso é o de Benjamin Franklin, mas ele era apenas um dentre um grupo diverso de professores universitários, demonstradores, inventores, fabricantes de instrumentos, vendedores de livros, eletroterapeutas, showmen, médicos itinerantes e outros empreendedores da economia elétrica transatlântica dos séculos XVIII e XIX ${ }^{17}$. Ao passo que tais circulaçôes eram no tempo de Franklin amplamente preservaçáo de uma elite gentílica, no meio do século XIX os direitos civis haviam se expandido consideravelmente. Isso é evidente nos Estados Unidos, pelo menos, no florescimento do circuito de leitura de liceu, que no seu auge em 1850 era esclarecedor e divertia públicos estimados em 400.000 pessoas por semana. A cidade de Nova Iorque sozinha recebeu mais de 3000 leituras públicas anunciadas entre 1840 e 1860 , enquanto que no resto do país, mesmo nas menores cidades, leituras eram organizadas por associaçōes de homens jovens, sociedades de bibliotecas, institutos de mecânica e outras instituiçôes civis ${ }^{18}$. Autores perió-

${ }^{16}$ Ver, por exemplo, Donald Zochert (1976, p. 7-32). Para um estudo exemplar sobre publicação científica popular na Grã-Bretanha do século XIX, ver Fyfe, Science and Salvation.

${ }^{17}$ Sobre a história da exibição elétrica na América dos séculos XVIII e XIX, ver sobretudo James Delbourgo (2006, p. 87-128); Fred Nadis (2005, p. 3-82). De modo mais geral, sobre as demonstraçôes públicas de eletricidade no final do século XVIII e início do século XIX, ver Iwan Rhys Morus (1998); Rhys Morus (2009, p. 263-75); Schaffer (1983, p. 1-43); Schaffer, (1993, p. 489-526); e Bernadette Bensaude-Vincent and Christine Blondel (2008).

${ }^{18}$ Donald M. Scott (1980, p. 791-809). 
dicos, instrutores de liceu e agentes comerciais de dispositivos elétricos para divertimento, edificação e terapia médica então compreendiam uma classe em desenvolvimento de popularizadores de ciência: figuras que pareciam familiarizadas com os últimos avanços da comunidade científica profissional, mesmo quando seus discursos e atividades eram marcados como meramente amadores, comerciais ou simplesmente não científicos.

Os espiritualistas não eram excluídos desses circuitos de visibilidade científica em expansão. Andrew Jackson Davis (1826-1910) era o mais proeminente dentre essas figuras públicas. Um polímata autodidata, médium e fourierista comprometido, Davis foi nomeado por um de seus pares como o "João Batista" do movimento espiritualista" ${ }^{19}$. Ainda que Davis mesmo tivesse uma relação desconfortável com alguns ramos do espiritualismo (ele reservava sua crítica mais feroz para os extravagantes médiuns teatrais, os quais ele não hesitava em denunciar como fraudes e como charlatóes que colocavam em risco a comunidade espiritualista legítima), sua influência no movimento como um todo é dificilmente exagerada. Os esforços editoriais de Davis foram gigantescos, abrangendo quatro décadas e dúzias de livros e panfletos. Além do mais, ele ocupava uma posiçáo de destaque como editor de periódicos espiritualistas como o The Univercoelium and Spiritual Philosopher (de 1847 a 1849) e o The Herald of Progress (de 1860 a 1864) ${ }^{20}$. Todos os tópicos de interesse dos leitores espiritualistas passavam pelo crivo de Davis: conselhos conjugais, propostas de reforma política, comentários a respeito de descobertas médicas e científicas e aparentemente infinitas descriçóes a respeito do mundo após a vida e de seus habitantes ou sobre a fauna e a flora de planetas distantes que Davis havia visitado no estado

${ }^{19}$ A popular organizadora espiritualista e historiadora contemporânea do Espiritualismo estadunidense Emma Hardinge, saudou Davis como uma figura do tipo João Batista, que preparou o caminho para o florescimento do movimento (citado em Albanese, Republic of Mind and Spirit, p. 206).

${ }^{20}$ Sobre a biografia, carreira e produção literária de Davis, ver Albanese (1992, p. 1-17); Robert W. Delp, (1967, p. 43-56). 
de transe. Em todos esses esforços, ele se apresentava como uma espécie de oráculo moderno, canalizando conhecimento e sabedoria que emanava além do nosso mundo de experiências diárias em forma de presentes, avisos e revelaçóes sobre as condiçōes verdadeiras da nossa existência mortal e da nossa alma imortal. Ainda mais surpreendente, no entanto, é a maneira como os textos de Davis são formatados pela sintaxe científica de descobertas, observações, descriçôes e explicações sobre as causas.

Davis não era o único espiritualista que parecia familiarizado com as últimas descobertas e conquistas da eletrofísica, da fisiologia, da astronomia e da engenharia elétrica. Como seguidores interessados de notícias científicas, muitos escritores espiritualistas estavam em boa posição para tirar proveito dos circuitos em expansão de publicaçôes sobre ciência popular e profissional que indicaram o meio do século XIX como o momento de nascimento do que futuramente viria a ser um mercado massivo para os textos de ciência popular $^{21}$. Pode-se entáo falar de uma classe de intelectuais cuja tarefa era chegar à conclusôes sobre as verdadeiras liçôes sendo reveladas pelos avanços científicos e tecnológicos a respeito da ordem invisível da humanidade, do mundo e do cosmos. Essa classe incluía figuras que habitavam tanto o mundo acadêmico como a esfera pública espiritualista, como o professor de química Robert Hare (1781-1858) que se converteu ao espiritualismo tardiamente em sua vida, e o professor de geologia e psicometrista William Denton (1823-1883). Essa classe também incluía professores e pregadores de ciência itinerantes, como o ministro unitário e John Murray Spear (18041887), um receptáculo para instruçôes detalhadas fornecidas por agentes espirituais para construção de numerosas maravilhas tecnológicas, incluindo uma máquina de movimento perpétuo, um navio elétrico impulsionado por

${ }^{21}$ Sobre o editorial de ciência popular do século XIX, ver Louise Henson, Geoffrey Cantor, Gowan Dawson, Richard Noakes, Sally Shuttleworth, and Jonathan R. Topham (eds.). (1985, p. 549-72) e 2004 . 
baterias psíquicas, um veículo capaz de levitar e uma máquina de costura capaz de funcionar sem que alguém precisasse operá-la. ${ }^{22}$

Como membro desse grupo maior de mediadores de conhecimento espiritualista, Davis ofereceu formulaçôes que não eram incomparáveis, mas que, não obstante, destacam-se como excepcionalmente lúcidas e atraentes com as descobertas científicas e desenvolvimentos tecnológicos de sua época. Considere, por exemplo, o intenso envolvimento de Davis com a telegrafia, uma tecnologia cuja história de nascimento e expansão é precisamente paralela à história do movimento espiritualista em si (como muitos espiritualistas apontaram). Telegrafia era para Davis um tropo principal. Em resposta à pergunta de um dos leitores, impressa em uma edição de 1860 do The Herald of Progress, ele discorreu sobre as relaçóes entre os espíritos e os vivos da seguinte maneira:

A sublime ciência da telegrafia espiritual está ainda escondida nas leis da açáo e reação que permeiam, e que obviamente governam, todas as formas e gradaçóes de matéria. Cada parte da mente e cada centro ganglionar no departamento visceral tem sua própria afinidade. Essas afinidades são distintas e disponíveis. Os órgãos superiores geram influências exaltadas e expansivas que radiam por todos os outros órgãos no mesmo corpo e externamente para enormes distâncias. Essas influências tocam e afetam positivamente de maneira similar os órgãos e as centrais correspondentes em outras pessoas, estando elas presentes ou não. (Davis, 1860, p. 1)

Para Davis, o que faz o telégrafo "sublime" é a presença subjacente de um conjunto fundamental de leis de ação e reação que governam todas as maneiras possíveis de contato, comunhão e união de afinidades entre as partes do corpo, entre interlocutores próximos e distantes, e mesmo entre

22 Sobre Hare, ver Craig James Hazen (2000, p. 65-112). Sobre Spear, ver John Benedict Buescher (2006). O clássico trabalho de William Denton sobre psicometria apareceu em seu livro The Soul of Things: Psychometric Experiments for Re-Living History (Boston, 1863). 
os vivos e os mortos. "Não há apenas uma lei projetada exclusivamente para governar a mente e outra para governar a matéria", Davis afirma. "As leis da mente e as leis da matéria são a mesma e almas e estrelas se movem e se regulam pelo mesmo grande princípio geral. Atração governa tudo" (Davis, 1884 , p. 286). Devo voltar a considerar amplamente o que Davis pretendia com o termo "atração", mas, no momento, permita-me sublinhar a decisão de Davis de referir-se à comunicação entre corpos e mentes e espíritos como links telegráficos. Essa escolha de palavras reflete a consciência aguçada de Davis a respeito dos efeitos da tecnologia de mídia emergente nos limites existentes de espaço e tempo em um dado momento histórico quando as operaçóes telegráficas já haviam começado e abrir novas maneiras de perceber objetos científicos para sugerir novas possibilidades de comunicação e ação dentro de um universo cada vez mais compreendido como governado pelas leis de fluxo elétrico. Em resposta a um leitor em dúvida, Davis elaborou essa "lei da atração" com referência a uma grande variedade de relaçóes mediadas pelo telégrafo:

O que é verdadeiro de dois indivíduos aplicar-se-á igualmente a naçóes ou reinos. A lei psico-telegráfica de uma alma isolada, nos segredos de sua constituição dual, é a lei da telegrafia entre quaisquer almas em quaisquer distâncias. Qual é a lei e quais são as condições de sua operação no indivíduo? Brevemente essas: os pés telegrafam suas sensações para o cérebro. Há centenas de obstáculos materiais e proeminências entre eles, no entanto eles se afinam e se comunicam. Os pés dizem: "Eu sou simplório e sinto dor de tanto caminhar". A mente recebe essa mensagem telegráfica e responde: "Você receberá conforto". Os pés respondem: "Obrigado, espero que você mantenha sua promessa”. Nessa maneira familiar, cada órgão se comunica com o outro e então todos eles, individual e coletivamente, reportam ao quartel-general, ao local reconhecido universalmente como de governo, ao cérebro que está em posse de toda a existência organizacional. (Davis, 1860, p. 1)

Assim como o pé e o cérebro estão em contato somente graças à presença de "cordas sutis de contato simpático", elos similares podem ser forjados 
"entre duas almas afins" (Davis, 1860, p. 1). Comunicação então consiste em "um concerto melodioso de doces afinidades... após as quais, não obstante grandes distâncias podem comungar no princípio da telegrafia magnética" (Davis, 1860, p. 1). Telegrafia serve aqui muito mais do que como uma metáfora para comunicação espiritual, é um modelo para orquestrar e coordenar açóes entre corpos, mentes e almas afins conectados. Em outro texto, Davis explica como tais telegrafias espirituais funcionam:

Suponha que uma mãe, morando em Nova Iorque, reze por notícias sobre seu filho que mora em Londres. Ele está muito doente. Ela está ansiosa para saber de sua situação social. Levará entre dez e vinte dias para que ela receba uma carta. Mas ela precisa saber agora. Como? Ela não é clarividente, mas ela é uma médium para impressão... O que isso significa? Isto é, os órgãos, situados na parte superior da cabeça, só são acessíveis por influência espiritual. Muito bem. A mãe tem espíritos guardiães no plano espiritual e seu filho também. Eles percebem e entendem a ansiedade da mãe e a condição do filho. Então, eles se aproximam da atmosfera em torno do nosso globo. Como os habitantes da Terra, os guardiães dela e do filho foram um círculo de simpatia... O círculo sobre humano estabelece linhas de simpatia entre a mãe e o filho, como indicado pelas correntes piramidais que conectam as duas cidades. Portanto, a condição real do filho é impressa na mente da mãe, telegrafada por assim dizer, tão perfeitamente quanto qualquer objeto pode ser pintado sobre qualquer órgáo físico de visão (Davis, 1886, p. 281-82). (Ver figura 2.) 
Figura 2 - "Clarividência e Impressão Espiritual".

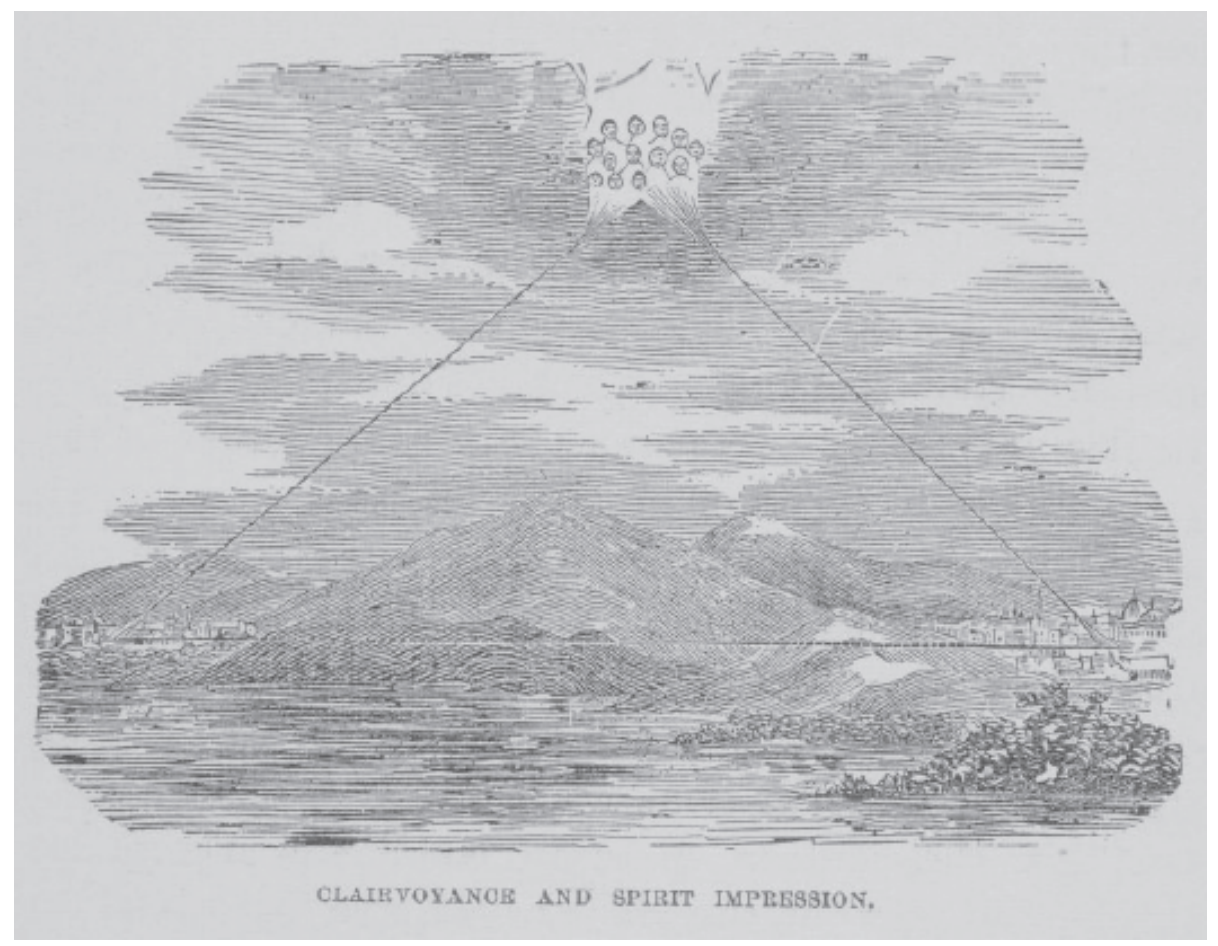

Fonte - Andrew Jackson Davis, The Present Age and Inner Life; Ancient and Modern Spirit Mysteries Classified and Explained (Boston: Colby \& Rich, 1886), p. 280. (Reprodução cortesia da Rare Books and Special Collections, McGill University Library.)

As seções subsequentes deste texto serão uma tentativa de revelar o aglomerado de temas sobre linhas sobre-humanas de simpatia, contato à distância e o poder da visão invocada nos trechos anteriores. No momento, note-se que a descrição de Davis sobre a telegrafia espiritual, ou a função e o propósito dos cabos de magnéticos nas práticas de séance que formava somente uma pequena parte do extensivo discurso espiritualista sobre o funcionamento de nervos, cabos telegráficos e outros sistemas de mídia e 
seus princípios eletromagnéticos subjacentes de circularidade, polaridade e conduçáo linear.

De fato, uma apreciação da afinidade eletiva entre comunicação espiritual e telegrafia eletromagnética abundante na literatura espiritualista, começando por descriçôes sobre batidas similares às do código Morse das irmãs Fox ou com a escolha do título do primeiro periódico publicado, The Spiritual Telegraph ${ }^{23}$. Contatos mediados telegraficamente entre espíritos e os vivos foi amplamente noticiado nesse período. James Mansfield, o "Chefe dos correios espirituais" residente em Sáo Francisco, foi conhecido por entrar em transe e tamborilar grandes mensagens em código Morse com seu dedo indicador, "como o movimento de uma chave telegráfica" (Cox, 2003, p. 20). Práticas de cura mediúnica eram também frequentemente descritas como dependentes de uma forma de condutividade elétrica: a uniáo exitosa entre paciente e curandeiro e a formaçáo de um circuito de forças eletrobiológicas que poderiam ser manipuladas para estimular ou acalmar o corpo, aliviar a dor, curar doenças ou mesmo promover crescimento espiritual ${ }^{24}$. O tropo da fragilidade nervosa pode ter figurado em uma longa história de medicina ortodoxa como uma condição patológica, mas nos textos espiritualistas essa era a marca do aparato médium unicamente aprimorado e sensível a comunicaçóes do outro mundo, muito parecidos com o instrumento receptor da indústria telegráfica.

De um ponto de vista mais amplo, os dons mediúnicos do espírito de receptividade e condutividade das forças espirituais aparecem como um ponto

${ }^{23}$ The Spiritual Telegraph foi encontrado por S. B. Brittan e Charles Partridge e publicado em Nova Iorque de 1852 a 1860, até combinar-se com o próprio artigo de Davis, The Herald of Progress.

${ }^{24}$ Alex Owen relata como os espiritualistas britânicos tipicamente entendiam a relação de curandeiro mediúnico e paciente em termos de transferência de energia, frequentemente descrita como uma força magnética ou eletrobiológica que o curandeiro poderia trocar pela "vitalidade reduzida" do paciente durante os atos de ligação íntima, que poderia consistir em diagnóstico durante estados de transe ou imposição de mãos; ver Owen, Darkened Room (1989, p. 109-10). 
terminal dentro de um sistema comunicacional de proporçôes cósmicas. Essa comunidade espiritual era integralmente ligada, como o vidente norte-americano Hudson Tuttle colocou, por "cordas simpáticas... como fluido elétrico no fio telegráfico” (Cox, 2003, p. 88). O céu e a terra em si são unidos, nas palavras de Cora Daniels, uma das mais famosas médiuns americanas do século XIX, por "telegrafia constante... como sensaçóes disparadas sem que um segundo sequer seja perdido" (Cox, 2003, p. 89). E, como relatado em uma comunicação de transe para o médium Abraham Pierce, parece que não muito depois de chegar ao paraíso os espíritos são encarregados de aprender os fundamentos da telegrafia para poderem contatar os que ficaram para trás. Ainda mais notavelmente, Pierce anunciou, conforme os espíritos progridem nos rankings das esferas paradisíacas, a educação deles continua segundo eles adquirem conhecimento sobre coisas como construção de estradas e sistemas ferroviários, até que eles atinjam a mais alta esfera celestial na qual embarcam nos estudos anatômicos do sistema nervoso em si. A própria ideia de uma corda magnética não pode ser compreendida fora do contexto de um discurso maior sobre comunicação telegráfica, que no meio do século XIX servia como uma marca da contaminação mútua entre círculos científicos e não científicos.

\section{NERVOS, CABOS E A LÓGICA DO SINAL}

Para os espiritualistas, entre muitos outros interlocutores do meio do século XIX, os cabos telegráficos e os cabos magnéticos feitos em casa pertenciam à mesma categoria, porque ambos serviam à mesma lei fundamental de atração e repulsão mútua que parecem governar o universo e, mais especificamente, porque eles compartilham o mesmo conjunto de características organizacionais que vieram a ser vistas como requisitos essenciais para transmissão de diversos tipos de energia e de informação. Nesse sentido, não é surpreendente que espiritualistas tenham abraçado tão prontamente o telégrafo, tanto como uma analogia da comunicação espiritual como um modelo para organização de 
atividades de séance. O telégrafo, afinal, é conhecido como uma das grandes revoluçôes de comunicação do século XIX, rompendo relaçôes espaço-temporais de centro e periferia e de proximidade e distanciamento, inaugurando uma nova era de conectividade global, hipermobilidade e supraterritorialidade. Como o primeiro meio de comunicação baseado em transmissão elétrica, o telégrafo estendeu-se dos domínios mais sóbrios da física da energia, engenharia, comunicaçóes diplomáticas e transaçóes financeiras até um terreno muito amplo de cultura popular e ciência pública ${ }^{25}$. Como pode-se ver, o telégrafo também ajudou a tornar inteligível uma variedade de fenômenos fisiológicos que pareciam envolver conexôes entre a mente e o corpo, mais evidentemente no caso do sistema nervoso. Como a sua contraparte terrestre, para os observadores do século XIX, os nervos pareciam funcionar indexadamente: como um sistema de sinais que liga o processo de sensação, impulso e reação corpóreo imanente ao processo simbólico "transcendente" de cognição, representação e memória.

${ }^{25}$ Apesar de uma volumosa literatura sobre o papel da telegrafia no século XIX ter se desenvolvido em sua sequência, a declaração "clássica" sobre a revolução inaugurada pelo telégrafo é de James Carey, (1989, p. 155-76). É sempre um negócio arriscado tentar periodizar processos de mudanças tecnológicas rápidas (até porque os efeitos de novas tecnologias de mídia são experienciados de acordo com uma geografia desigual, na qual eles se espalham), mas falando de modo grosseiro, o ano de 1890 serve como um limite útil para dividir nós dos nossos antepassados do século XIX, cujos sentimentos e açóes eram revestidas pela arquitetura representacional do sistema nervoso. Eu recorro a 1890 como o momento inaugural de mais uma mudança tecnocultural, baseada nos princípios emergentes de conectividade sem fio, centelhadores, ressonâncias harmônicas e outros modos de representar espaços intersticiais entre corpos (dramatizados através de experimentos em laboratório e através da introdução de novas tecnologias de mídia como o transmissor de rádio, o eletroencefalografia e o espectroscópio). Desde que esses desenvolvimentos anunciaram novos alinhamentos de ciências legítimas e marginais, arranjos tecnoinstitucionais e práticas culturais (incluindo um novo vocabulário cosmológico), eles vêm marcando um afastamento distinto das preocupaçóes da presente discussão. Sobre a afinidade entre o Espiritualismo do fim do século e a tecnocultura emergente do "sem fio", ver principalmente Anthony Enns (2008, p. 137-52). 
Imagens de um circuito em rede derivaram da indústria do telégrafo em desenvolvimento e encontraram seu caminho nas especulações cosmológicas dos escritores e palestrantes espiritualistas pelo mundo Atlântico. Retoricamente posicionada como um veículo de transcendência e de desencarnação instantânea, a comunicação telegráfica manifestou não só o mistério da eletricidade como também concepçôes arcaicas de união mística e de presença espectral dos mortos. De fato, no momento em que David havia escrito suas descriçôes sobre a comunicaçáo espiritual, já havia virado lugar comum descrever a ordem cósmica como uma vasta teia de rotas em rede, fios finos, canais e linhas relacionadas de comunicação. O sinal telegráfico forneceu indiscutivelmente a figura mais atraente sobre a qual modelar o contato e a comunhão com o distante, sejam essas distâncias no próprio corpo, entre países ou além do domínio do mundo dos vivos.

Similar a um cabo transmitindo uma carga elétrica, a mediunidade do espírito era frequentemente descrita como um meio de manifestaçáo de forças de origem distante e de transportar impressóes para um receptor local. A infraestrutura tecnológica necessária para o recebimento de mensagens espirituais era o corpo humano em si. Para Davis, como para inúmeros de seus contemporâneos espiritualistas, o espetáculo da mediunidade do espírito poderia ser atribuída a "[...] um tipo de magnetismo espiritual que somente algumas pessoas com temperamento e organização particularmente negativos estariam adaptadas para receber... um certo estado de suscetibilidade mental, no qual o sistema nervoso humano é excessivamente impressionável [...]", permitindo que tais indivíduos recebam comunicações espirituais "[...] por meio de vibraçôes ou ondas respiratórias que passam do sistema nervoso até o cérebro e acordam pensamentos por impressão" (Davis, 1853, p. 173-174). Assim como "[...] o cérebro é ligado à medula espinhal, o coração é relacionado com as artérias, os nervos são relacionados com os órgãos e os músculos e todos os sistemas são relacionados com os ossos [...]", Davis adotou a figura do circuito em rede para explicar a existência de "[...] uma cadeia conectada de correspondências invisíveis... elevando o voo sinuoso de escadas que conduzem dos ossos até o cérebro, [chegando] por passos finamente graduados no espírito, que 
incessantemente elabora por meio de vários sistemas de poderes e relações sob seu controle" (Davis, 1871, p. 128-29). Comunicação espiritual, em outras palavras, somente era possível por meio da organização do corpo humano e da mente em uma espécie de circuito telegráfico no qual "[...] a arma, dentro da mente e da medula espinhal e difundida por todos os gânglios simpáticos sente instantaneamente cada transação em cada parte do corpo" (Davis, 1871, p. 103-04). Como elaborado por Davis:

Não só o cérebro é uma grande bateria, composta de inúmeras baterias pequenas interligadas, chamadas de células nervosas ou de centros nervosos, mas a mente é também uma grande uniáo de centro telegráfico no qual são recebidos e transmitidos inúmeros tubos e condutores chamados de células sanguíneas, uma pequena bateria com outra; elas juntam grupos positivos de células ou centros com seus correspondentes negativos de maneira sistemática e harmoniosa tal que é impossível atingir uma ligação na cadeia cerebral e não perturbar ao mesmo tempo mais ou menos toda a cadeia de sentidos e inteligência. (Davis, 1871, p. 114).

Para apreciar como um autor como Davis conseguia táo prontamente mover-se entre discussóes sobre telegrafia, anatomia do sistema nervoso e os segredos da comunicação espiritual, é útil lembrar de quais maneiras alguns desses mesmos paralelos estavam sendo forjados em discursos de profissionais médicos e cientistas ao longo da primeira metade do século XIX. Historiadores identificaram uma mudança de paradigma decisiva nas ciências biológicas ao ponto de as explicaçôes do século XVIII com base nas teorias vitalistas do corpo, seus humores e seus sistemas hidráulicos de válvulas e tubos para circulação dos fluidos vitais tornaram-se cada vez mais precárias ${ }^{26}$. No começo do século XIX, o sistema nervoso já havia sido

26 Sobre a história das concepções do sistema nervoso desde a antiguidade até a modernidade, e especialmente as mudanças principais promovidas pelo desenvolvimento da neurologia, neuro-anatomia e fisiologia no começo do século XIX, ver Pietro Corsi, (1991); Laura Otis (2001); George S. Rousseau, (2004); Laura Salisbury and Andrew Shail, (2010, 
"funcionalmente reinventado" (Salisbury; Shail, 1765, p. 13), de acordo com Laura Salisbury e Andrew Shail. Avanços na microscopia pareciam indicar que os nervos eram entidades sólidas e, portanto, necessitava de novas explicaçóes a respeito de seu funcionamento e propósito dentro dos sistemas corporais para comunicações de sensação, percepção e ação. Estudos sobre o funcionamento de sistemas de percepção sensorial, açôes reflexas e outros processos corporais autônomos apontaram para um novo modelo de corpo humano, no centro do qual estava localizado o sistema nervoso governado por suas próprias regras funcionais. Johannes Müller (1801-1858), em Elements of Physiology (1833), argumentou que havia uma relação inteiramente arbitrária entre estímulo e resposta e que experiências específicas de sensação eram simplesmente resultantes das propriedades organizacionais do sistema nervoso em $\mathrm{si}^{27}$. Tais descobertas levaram a um consenso de que nervos deveriam ser percebidos anatomicamente e experimentalmente como "sistemas de mídia”, governados por uma lógica de sinal, cujas arbitrariedades dependiam da separação funcional do remetente (ou agente estimulante), do meio de transmissão e do aparato de recepção ${ }^{28}$. Os sucessores de Müller, incluindo seu mais famoso estudante, Hermann Von Helmholtz (1821-1894), deram ainda mais força para esse argumento comparando explicitamente o funcionamento da sinalização dos sistemas

1-40); Gordon M. (1991). Como James Delbourgo documenta, houve predecessores à "reinvenção" dos nervos como um sistema de mediação elétrica, embora a tendência ainda fosse descrever os nervos como condutos de um fluido elétrico; ver Delbourgo (2006, p. 223-24, 235), Most Amazing Scene.

27 Como Müller propôs, a sensação de "ver a luz", por exemplo, poderia ser produzida por emanaçóes do mundo externo, mas facilmente poderia ser produzida por processos internos, como quando agentes químicos (como os narcóticos) são introduzidos na corrente sanguínea; ver Johannes Müller (1843), 714f. O texto de Müller apareceu pela primeira vez em 1833 e passou por diversas ediçóes. Para a discussão desse texto e sua influência, com uma referência particular às teorias em evolução da percepção sensorial, ver Jonathan Crary (1992, p. 88-93); Jonathan Sterne (2003, p. 60-62).

${ }^{28}$ Sobre esse ponto, ver Sterne (p. 61-62), Audible Past. 
nervosos biológicos com baterias, fios e instrumentos receptivos da indústria telegráfica. Para Helmholtz uma sensação que passa pelo sistema nervoso funciona como um sinal de sua causa, que, como uma mensagem telegráfica, deveria ser decifrada e interpretada somente nos limites das capacidades representacionais do seu aparato receptor, o cérebro. Em um trecho famoso, ele resume:

Os nervos têm sido frequentemente - e não erroneamente - comparados aos fios telegráficos. Tal fio conduz um tipo de corrente elétrica e não outro; ela pode ser mais forte ou mais fraca e mover-se em qualquer direçáo; ela náo tem qualquer outra diferença qualitativa. Não obstante, de acordo com os diferentes tipos de aparatos com os quais fornecemos suas terminaçóes, podemos enviar mensagens telegráficas, tocar campainhas, explodir minas, decompor água, mover ímãs, magnetizar ferro, desenvolver luz e assim por diante. É o mesmo com os nervos. A condiçáo de excitação que pode ser produzida neles, e é conduzida por eles, é, até agora, como pode ser reconhecida em fibras isoladas de um nervo, a mesma em todos os lugares. No entanto, quando a condição de excitação é levada para várias partes da mente ou do corpo ela produz movimento, secreção das glândulas, aumento e declínio da quantidade de sangue, vermelhidão e calor de órgãos individuais, e também sensações de luz, audição e assim por diante (Hermann von Helmholtz, 1885, p. 149). ${ }^{29}$

A implicação da comparação de Helmholtz é a de que os nervos constituem uma espécie de sistema de sinalização, cuja arbitrariedade é baseada no fato de que os pulsos de energia por eles transmitidos eram determinados por variaçóes no armazenamento e pela organização de uma variedade potencialmente infinita de entradas e saídas. Como Laura Otis argumentou, a “[...] descoberta de Helmholtz e seus contemporâneos de que o sistema nervoso biológico era comparável aos sistemas de mensagem mediadas eletronicamente estava fundada em um conjunto muito maior de convergências

${ }^{29} \mathrm{O}$ texto de Helmholtz foi publicado pela primeira vez em 1862. Esta passagem também é discutida por Jonathan Crary em relação à doutrina de Müller da "separação dos sentidos"; ver Crary (1993, p. 93), Techniques (p. 93); Sterne(2003), The Audible Past, 62 f. 
discursivas entre as ciências e as práticas técnicas de pesquisa em neuroanatomia, física da energia e engenharia elétrica no século XIX, ocasionando o aumento de um entendimento comum das características funcionais e operacionais de transmissão de pulsos de energia por meio de alternaçóes de corrente elétrica ${ }^{30}$. O que fez sistemas de sinalização discreta distintos uns dos outros foi simplesmente uma questão de organização espacial da rede e da composição do meio transmissor em si $^{31}$. Essa similaridade entre o sistema nervoso orgânico e as redes telegráficas era evidente não só para os médicos do século XIX como Helmholtz, mas também para engenheiros elétricos e outros participantes da indústria telegráfica em desenvolvimento. Era excessivamente comum descrever comunicaçóes telegráficas com o uso da linguagem corporal de forças vitais circulando por meio do que era visto como uma elaborada e ramificada árvore dendrítica de cabos telegráficos e estradas de ferro que conectam remetentes e destinatários dentro do corpo. Como um sistema nervoso orgânico, o telégrafo parecia consistir em uma extensiva rede de fios finos e vibrantes transmitindo informaçóes vitais de e para centros metropolitanos, conectando cidades do interior às cidades litorâneas, aos parceiros comerciais e territórios coloniais distantes. E, como o funcionamento de um corpo saudável, operaçóes telegráficas regulares

${ }^{30}$ Ver Otis (2001, p. 10-14), Networking.

${ }^{31}$ Apesar do seu entusiasmo em comparar nervos ao sistema de mensagem telegráfica, os fisiologistas da metade do século dificilmente eram ignorantes acerca das diferenças significativas entre mídia biológica e mecânica. Como relatado por Otis, em 1850, Helmholtz mediu a velocidade dos impulsos nervosos a uma velocidade de 26,4 metros por segundo, em um contraste visível com a condução de eletricidade através de fios de metal, como Charles Wheatstone, o inventor do sistema britânico de telégrafo de agulha, havia demonstrado em 1834, quando ele calculou que a eletricidade poderia atingir a velocidade de mais de 250.000 milhas por segundo (algo próximo a 1,45×109 km/h). "É evidente", conclui Otis, "[...] que os sistemas de comunicação vivos e os telegráficos não estão funcionando do mesmo jeito [...]"; Otis (2001, p. 27), Networking. 
ofereciam uma visão de harmonia social que repousava sobre os princípios da governança ordeira e da comunicação efetiva dentro de impérios e naçôes ${ }^{32}$.

Outro ponto de convergência, tanto dos discursos populares quanto dos científicos ocasionado pelo advento dos sistemas de comunicação baseados em eletricidade, pode ser encontrado no movimento espiritualista do século XIX. Há um paralelo tentador a ser desenhado entre a crescente fascinação popular com sonambulismo, transe hipnótico e outras instâncias da atividade inconsciente - certamente um terreno de interesse para espiritualistas, que lutavam para encontrar termos adequados para explicar e legitimar suas práticas de séance - e o desafio feito pelos especialistas em fisiologia à suposição de lugar comum de que a mente consciente, localizada no cérebro, é indiscutivelmente a autoridade central de coordenação de todos os processos mentais e físicos. $\mathrm{Na}$ época dos textos de Davis, um discurso fisiológico extenso havia entrado em voga; o sistema nervoso passava a ser tratado como um sistema autônomo de comunicaçôes, alimentado independentemente das operaçóes conscientes da mente. Em 1812, o médico Thomas Trotter (1760-1832) já havia descrito o sistema nervoso como uma rede de conexôes simpáticas, através da qual “[...] nervos eram agora vistos como comunicando uns aos outros, em vez de simplesmente executando os comandos do cérebro" (Citado em Salisbury; Shail, 1765, p. 16). No meio do século, pesquisas sobre açôes reflexas e outros processos autônomos do corpo, como respirar e digerir, haviam contribuído para afiar a distinção entre atividades cerebrais voluntárias e atividades motoras involuntárias. Rejeitando o senso comum de que a mente é a autoridade central de coordenação, os médicos começaram a questionar se as funçôes orgânicas do corpo não eram mais provavelmente controladas pelos gânglios do que era às vezes referido como o "sistema nervoso vegetativo", uma

${ }^{32}$ Ver Otis (2001, p. 455-75). 
rede de ramificaçóes emanando do "grande nervo simpático" que operava independentemente da rede nervosa cerebrospinal. ${ }^{33}$

Ao mesmo tempo que os médicos e os anatomistas comparativos estavam isolando o sistema nervoso como uma entidade independente do organismo, as fundações da medicina ortodoxa tinham chegado a considerar os nervos humanos como um importante campo de investigação da transmissão de doenças das células sanguíneas para o cérebro ou para a tradução de febres do corpo em comportamento maníaco, entre outras preocupaçóes com sensibilidade do corpo, enervação, fatiga e irritabilidade ${ }^{34}$. Alguns médicos inclusive lançavam mão de evidências neurofisiológicas para explicar os "perigos" do entusiasmo religioso - incluindo a mediunidade espiritualista entendida como produto de distúrbios mentais, enraizado em deformidades dos órgãos maiores, do sistema vascular e, acima de tudo, disfunçóes na mais vital rede de comunicação do corpo, o sistema nervoso. Experiências com

${ }^{33}$ Como argumentado pelo botânico e anatomista comparativo William Lauder Lindsay (1829-1880), “[...] a velha doutrina ou suposição dos frenologistas [...] que, a saber, considera o cérebro como o único órgão da mente, deve inquestionavelmente ser abandonada. Devemos, a partir de então, considerar a verdadeira zona, lugar ou órgão da mente como o corpo inteiro; e essa é a única base sólida na qual os fisiologistas comparativos podem começar seus estudos"; Lindsay, Mind in the Lower Animals, vol. 2, Mind in Disease (London: Kegan Paul, 1879), 4. O argumento de Lindsay baseiase no que na terça parte do século XIX era considerado como evidência incontroversa derivada da anatomia comparativa e experimentos com as partes do corpo de pequenos animais, como as pernas de sapos decapitados, cujos músculos eram já bem conhecidos por reagir à excitação dos nervos. Essa destituição do cérebro até levou alguns anatomistas comparativos a sugerirem que o cérebro de animais mais altos era meramente a "extensão crescente" do sistema de nervos mais fundamental e mais universal localizado ao redor da medula espinhal. Muito antes dos escritos de Lindsay, o cientista mais famoso a realizar o experimento com as pernas de sapos foi, sem dúvida, Luigi Galvani, cuja teoria da "eletricidade animal" era posteriormente desacreditada por Alessandro Volta; ver Marcello Pera (1992).

${ }^{34}$ Ver, por exemplo, Edwin Lee (1833); John O’Reilly (1860), especialmente 11-15, que fornece uma descrição típica do funcionamento cerebral "ao estilo bateria". 
testemunhos de manifestaçôes espirituais, estados de clarividência sonâmbula ou as emoções amplificadas e a agitação física que frequentemente acompanham tais eventos poderiam agora ser atribuídos a problemas de superestimulação ou "ligação defeituosa" fazendo com que a mente consciente se renda a comportamentos maníacos ${ }^{35}$.

Mas as autoridades médicas ortodoxas não eram os únicos comentaristas do espectro das açóes corporais e das experiências sensoriais que pareciam se desenrolar na ausência do controle mental consciente. No contexto da impressão mediada da esfera pública da modernidade burguesa transatlântica, suas vozes eram acompanhadas pelos diversos competidores com uma participação na interpretação das atividades notáveis que pareciam acontecer nas câmaras de séance pelo mundo. Escritores espiritualistas eram os mais determinados a zombar da autoridade da medicina ortodoxa. Contrariando os esforços dos médicos de alinhar a mediunidade espírita com a loucura, eles enfatizavam as sensibilidades rarefeitas dos médiuns espíritas e a plausibilidade técnica de que as revelaçóes do mundo espiritual poderiam ser manifestadas com o uso do equipamento certo. A incomparável arquitetura sensitiva do sistema nervoso de um médium espírita era espelhada no padrão distinto do círculo de séance e na implementação estratégica de dispositivos, como o cabo magnético, que poderia ajudar a estabelecer o balanço de forças necessárias para a recepção de energias espirituais. Revelaçôes do mundo espiritual agora pertenciam ao escopo de um fundamental e cósmico conjunto de leis de atração, propagação e recepção que governavam todas as relaçôes possíveis entre corpos materiais e agências e forças imateriais. No discurso espiritualista, essas leis eram tipicamente agrupadas dentro de um único termo: simpatia.

35 Sobre os esforços dos neurologistas do século XIX para investigar e diagnosticar tais fenômenos como sonambulismo e estados de transe, ver Edward M. Brown (1983, p. 563-77). De modo mais geral, na história das respostas médicas ao Espiritualismo (que normalmente tomava a forma de alarmismo e hostilidade por parte das instituiçôes médicas em relação aos médiuns espirituais), ver Braude, Radical Spirits, p. 142-61; Owen, Darkened Room, p. 139-67. 


\section{A ARQUITETURA DA SIMPATIA}

Em seu brilhante estudo sobre o Espiritualismo norte-americano do século XIX, Robert S. Cox (2003) apresenta a simpatia como um tropo essencial no pensamento e na prática espiritualistas, por ser um termo que abrange diversas conotaçôes, como de sentimento harmonioso, conexôes entre as partes do corpo ou o exercício de poderes ocultos de atração entre os mundos físico e espiritual. Para muitos leitores falantes da língua inglesa do século XIX, a "simpatia" evocava a moral filosófica de Adam Smith (1723-1790), que a definiu como um princípio fundamental de contato harmonioso e sentimento mútuo gerados entre grupos de pessoas com opinióes semelhantes. Para Smith, simpatia dependia do processo histórico de refinamento das sensibilidades humanas, ou seja, da evolução das restrições sociais e culturais da razão, da civilidade e da gestão firme das paixóes. Sua teoria foi recebida calorosamente entre os escritores do Iluminismo escocês e do norte-americano, em que era frequentemente interpretado como um apologético aos modos cristãos protestantes burgueses de devoção contida. O uso do termo simpatia por Smith também coincide com os discursos médicos predominantes da sua época, de forma mais evidente com o trabalho de seu colega de Edimburgo, o fisiologista Robert Whytt (também chamo de Whyte, 1714-1766), que havia postulado o sistema nervoso como a ponte central entre mente, corpo e ambiente, além de entendê-lo como a condição essencial para a possibilidade da produção de sensibilidade e sentimento mútuo. Entretanto, como Cox (2003) defende, no contexto da América do século XXI, a teoria de Smith havia se tornado "repleta de um conjunto de conotaçóes estranhas" (Cox, 2003, p. 30), entre as quais figuravam explicações de união simpática enraizadas no oculto. No caso específico do Espiritualismo, as experiências de sonambulismo, clarividência, psicografia e as manifestação de visóes e sons de espírito dentro da câmara de séance propiciaram aos espiritualistas ocasióes para reformular o conceito de Smith a fim de produzir o que Cox descreve como 
[...] uma teoria de comunidade baseada na prática social de comunhão simpática, um nexo transcendente de emoção que conectou e coordenou toda a vida e a morte. O Espiritualismo forneceu legibilidade para a vida, mapeando o cosmos para uma topografia diferenciada de emoção em que as geografias do corpo, paraíso e terra participam do processo de sutura do indivíduo fisiológica e socialmente nas estruturas perenes que animam o cosmos. (Cox, 2003, p. 70)

Cox está plenamente certo de que, na elaboração feita pelos espiritualistas dessa "topografia da emoção" cósmica, eles recorreram tão prontamente à autoridade dos discursos esclarecidos da filosofia moral e da medicina no que diz respeito às compreensóes ocultas da lei de atração mútua. Porém, eu adicionaria o discurso do eletromagnetismo como um enquadramento essencial para os esforços espiritualistas em visualizar, localizar e tirar vantagem do "nexo transcendente" ao qual Cox faz referência na citação anteriormente apresentada. Como venho argumentando nessa seção, o sistema nervoso espiritual operava não como um sistema de bombas e fluídos, de corpos percussivos e de gases difusos, mas sim como um tipo de circuito elétrico, que canaliza sinais e conecta mentes, corpos e objetos distantes (incluindo aqueles situados além do limite da sepultura) através do padrão figurativo de nervos, cabos telegráficos e outras redes eletricamente mediadas. Para Davis, a condição para a possibilidade de todas as formas de uniáo simpática - entre os vivos e os mortos - era a eletricidade. Mas eletricidade era simplesmente o nome que nós grosseiramente empregamos para nos referirmos às mais fundamentais, eternas e universais leis de atração que organizaram o cosmos em um conjunto coerente e proporcionaram à suprema agência divina do universo, a "mente divina", o seu meio de comunicação. Ele afirma:

Uma modificação de eletricidade nós chamamos de Magnetismo, outra de Galvanismo, outra de influência do nervo vital, etc.; ainda que esses termos sejam meramente expressivos do refinamento progressivo e manifestaçóes superiores do Grande princípio. A Mente Divina emprega a eletricidade como um meio de comunicação entre todas as partes e partículas do universo [...]. Na verdade, a eletricidade está em todo lugar e em todas as coisas. É o veículo ou 
meio da vitalidade divina. Ela está operando milagres nas reentrâncias secretas da terra; ela brinca nas abóbadas de diamante e nas câmaras sob o mar; ela voa de um ponto a outro nas camadas minerais mais profundas; ela penetra todos os oceanos e fornece essa bateria viva, a enguia-torpedo, com seu poder maravilhoso; em uma palavra, ela reside e preenche todas as substâncias da natureza, é a causa imediata de toda contração e repulsão e de toda expansão e atração que ocorrem na organização humana. (Davis, 1850, p. 282-83)

Como já começamos a perceber, na época de Davis, foi a apreciação das regras do comportamento da eletricidade sob condiçóes diversas que proporcionou a maior xibolete que divide as noçóes espiritualistas da comunidade simpática daquelas dos seus antepassados do século XVIII. Por exemplo, tanto Smith quanto seu compatriota, o filósofo David Hume (1711-1776), impuseram um limite geográfico significante à possibilidade de união simpática; como a gravidade, a simpatia deveria, supostamente, diminuir com a distância. Na formulação de Hume: “[...] a simpatia, temos que admitir, é muito mais fraca do que nossa preocupaçáo com nós mesmos, e a simpatia por pessoas distantes de nós é muito mais fraca que por pessoas próximas e contíguas." (Hume, 1751, p. 99). ${ }^{36}$ Se, no século XVIII, às vezes imaginavase que a eletricidade tinha algo a ver com essas conexóes simpáticas através do espaço, era mais provável que se referisse à visão amplamente aceita de Benjamin Franklin de uma economia autorreguladora de cargas positivas e negativas. Franklin, depois de tudo, havia atribuído à eletricidade uma tendência inerente à restauração do equilíbrio através do balanceamento das forças positivas e negativas, proferindo uma contrapartida "natural" da imagem da governança moral defendida por filósofos escoceses como Smith e Hume. ${ }^{37}$

36 Para uma comparação perspicaz de Hume e Smith sobre as dimensões espaciais da simpatia, ver Fonna Forman-Bazilai, Sympathy in Spaces: Adam Smith on Proximity, Political Theory. v. 33, n. 2, 2005, p. 189-217.

37 Sobre a concepção de Franklin da eletricidade como uma balança de cargas positivas e negativas, ver Delbourgo, Most Amazing Scene, p. 31-41 et passim. 
Mas a segurança das suposições estruturais sobre contiguidade, proximidade e equilíbrio foram radicalmente desafiadas ao longo do século XIX, muito em razão da disseminação das novas tecnologias de telecomunicaçôes - a começar pelo telégrafo eletromagnético - que estavam dramaticamente revisando as noçóes aceitas de distância espacial e temporal. Como nós já vimos no caso de Davis, os espiritualistas da metade do século XIX não tiveram que procurar muito para encontrar exemplos extraídos da indústria telegráfica em expansão, e esses escritores não tiveram menos recursos para desenvolver cenas científicas de investigação e experimento com a propagação de forças elétricas. Uma dessas cenas de investigação, discutidas na seção anterior deste artigo, foi construída ao redor do estudo fisiológico do sistema nervoso, funcionalmente reinventado como um sistema de sinalização elétrica intracorpórea, e, nesses termos, apresentando um incitamento para até mesmo dispensar as suposiçóes de que o cérebro, como lugar da razão, possuía pleno domínio sobre as relaçóes de estímulo e resposta para as quais a noção de simpatia apontava.

Se Smith pode ter achado difícil imaginar esse cenário de um corpo humano funcional deixando a autoridade reinante da mente e do cérebro, ele pode ter achado um mundo ainda mais estranho o de conexóes invisíveis que estava emergindo no contexto dos experimentos e teorizaçóes de eletricidade e magnetismo do século XIX para o qual não havia orientação suficiente que pudesse ser fornecida pelo léxico franklinista de uma economia autorreguladora, muito menos pelos relatos menos instruídos da eletricidade como um fogo misterioso ou fluido. No início do novo século, o filósofo dinamarquês Hans Christian Oersted (1777-1851) demonstrou como uma agulha magnetizada poderia ser movimentada quando colocada próximo a um fio condutor de eletricidade, assim estabelecendo um sério desafio para a suposição difundida de que eletricidade e magnetismo são fenômenos completamente distintos. No final de 1820, o físico francês André-Marie Ampère (1775-1836) procurou determinar as relações exatas entre o fluxo da corrente e magnetismo fazendo um experimento com forças circulares geradas por um campo magnético integrado ao redor de um circuito fechado de corrente elétrica. Por volta de 1830, o cientista britânico 
Michael Faraday (1791-1867) estabeleceu a base da indução eletromagnética e introduziu o conceito de "linhas de força" como uma explicação da relação entre corpos distantes e campo magnético, apesar da natureza exata dessas linhas de força ter continuado incerta. ${ }^{38}$ Não houve novas respostas para o enigma de Faraday até 1860, quando James Clerk Maxwell (1831-1879) demonstrou a equivalência matemática da eletricidade, do magnetismo e da luz como variantes de um único fenômeno - o campo eletromagnético - que ele teorizou como sendo constituído por minúsculas rodas giratórias elásticas que enchiam o éter e tornavam possíveis todas as maneiras de comunicação entre suas partes. $\mathrm{O}$ que estava ficando cada vez mais claro para os físicos do século XIX era que eletricidade e magnetismo eram bem mais do que simples erupçóes discretas de energia em um universo regido por leis mecânicas de interação entre os corpos massivos; em vez disso, o eletromagnetismo era uma manifestação de um fluxo mais fundamental de forças responsáveis pela exata formação do universo e pela coexistência de todos os seus elementos constituintes. Dentro desse universo, linhas de força permeavam e operavam de maneiras que frequentemente pareciam desafiar suposições mecanicistas mais antigas sobre tais questóes, como a transferência de energia (como o calor) entre corpos ou o impulso e a inércia de seus movimentos no espaço. ${ }^{39}$

38 Para uma discussão clara de como Faraday conceituou a gravidade, a radiação e a eletricidade, e as suas possíveis relações com a transmissão mediúnica, a transmissão, propagação e a entidade receptora, ver Michael Faraday (1855, v. 3, p. 407-37); originalmente publicado em Philosophical Magazine (June 1852).

39 Por volta de 1880 , foram tomadas outras medidas que contribuíram para o desmembramento do modelo linear de transferência de energia elétrica e sua substituição por modelos mais “radiantes”. Em 1884, por exemplo, John Henry Poynting (1852-1914) demonstrou que correntes elétricas não circulam dentro de fios condutores, mas sim no espaço vazio que os circunda. Sobre Poynting e seus contemporâneos alunos de Maxwell, ver Bruce J. Hunt, Lines of Force, Swirls of Ether. In. From Energy to Information: Representation in Science and Technology, Art and Culture, ed. Bruce Clarke and 
É difícil determinar o grau preciso em que os espiritualistas estavam familiarizados com esses desenvolvimentos no estudo da física elétrica, mas não podemos deixar de notar a proliferação de definiçôes da união simpática, da comunicação espírita - e, de fato, dos funcionamentos mais profundos do cosmos como um todo - que, em vez de dependerem da linguagem da magia, do milagre ou do mistério impenetrável, reuniam especificamente termos eletromagnéticos de referência. Uma noção, a polaridade magnética era particularmente importante para os entendimentos espiritualistas tanto da organização do universo físico quanto da organização da "mais elevada" ordem cósmica na qual os espíritos residem. Se simpatia fosse meramente uma expressão de lei de atração mais universal, a ideia de polaridade magnética ofereceria meios cruciais de mapear as forças cósmicas que permitiram uma comunicação simpática entre as suas partes constituintes, incluindo o relacionamento entre almas da vida e da morte. De fato, ao longo dos trabalhos de Davis, os tropos franklinistas de polaridade elétrica e atração e repulsão magnética formavam parte de uma dualidade estrutural recorrente mais ampla que moldou suas muitas discussóes sobre a vida, a morte e o cosmos. Polaridade eletromagnética, então, referenciava (e poderia ser trocada por) outros binarismos, incluindo aqueles de macho e fêmea, razão e paixão ou calor e frio. Apesar do cabo magnético, nós podemos relembrar, supostamente ter sido construído a partir de dois elementos - um fio feito de cobre e outro de prata - cuja dualidade seria replicada no arranjo de gêneros dos assistentes em torno do círculo séance ${ }^{40} \mathrm{~A}$ polaridade também forneceu uma estrutura fundamental que controla as comunicaçóes dentro

Linda Dalrymple Henderson (Stanford: Stanford University Press, 2002), p. 99-103; cf. Enns (2008), "Psychic Radio," 142.

${ }^{40}$ Diversos historiadores do Espiritualismo do século XIX notaram a equaçáo da feminilidade com polaridade magnética negativa, o que, por sua vez, serviu como uma legitimação retórica para associar mediunidade com irracionalidade (tanto entre defensores quanto entre difamadores do movimento, por razóes opostas); ver, por exemplo, Braude (1989), Radical Spirits, 24; McGarry (2008), Ghosts of Futures Past, p. 46, p. 51, p. 158-59; e Owen (1989), Darkened Room, p. 14-15. 
do corpo, que era frequente e explicitamente descrita como um processo binário de transmissão e recepção de forças positivas e negativas. Em uma meditação sobre o funcionamento do sistema nervoso, Davis escreveu:

Cada nervo, embora fino como um fio e delicado, é composto por dois cabos distintos - as linhas ou condutores positivos e negativos -, cada um tendo uma função distinta e separada para realizar na economia orgânica. O nervo positivo é preenchido com uma substância condutora essencialmente diferente da substância que preenche o nervo negativo, e ambos ficam deitados lado a lado em um revestimento membranoso e cumprem diferentes funçóes com a mais perfeita harmonia e reciprocidade [...]. Esse magnífico sistema nervoso dentro do corpo humano é o elo de ligação entre a vida inferior e o instinto da constituição espiritual. [...] todas as partes do corpo estâo simpaticamente relacionadas e atadas pelos laços afetivos, formando uma fraternidade de interesse e reciprocidade de funçóes e tornando totalmente impossível para um membro sofrer sem que isso afete a saúde e a prosperidade de todas as outras partes. (Davis, 1860, p.4-5).

Os laços afetivos que constituíam a simpatia eram, portanto, estruturalmente e espacialmente dependentes da presença de polos magnéticos e das linhas de força que esses polos estabeleciam dentro do corpo. A polaridade magnética também oferecia a estrutura arquitetônica através da qual as relaçôes simpáticas poderiam ser estendidas para além do corpo: ao longo dos "fios finos e invisíveis" de força que conectavam mentes e corpos humanos com objetos e lugares distantes. Em um texto, Davis deixa claro o quanto ele e seus contemporâneos tinham se afastado da concepção de simpatia do século XVIII ao sugerir que as leis de atração e repulsão que governavam o funcionamento do sistema nervoso corporal podem ser aplicadas com a mesma facilidade à interação de corpos físicos na natureza, e até mesmo às forças gravitacionais que situam o planeta Terra em relação ao sol e aos demais planetas e estrelas da galáxia. Ele escreveu: 
A terra na qual nós vivemos é uma máquina elétrica giratória [...], uma imensa bateria magnética [...]. O movimento da eletricidade [...] é espiral. Com a rapidez além da imaginação, a eletricidade da terra corre em grandes faixas e enrola-se em seu próprio carretel natural no norte. O polo norte magnético [...] é uma hélice magnética imensa, um cabo enrolado de modo atmosférico, para as múltiplas correntes elétricas surgindo de todas as partes do globo. (Davis, 1878, p. 81-82).

A linguagem usada aqui para descrever o planeta Terra, sem dúvidas, parece de alguma forma vaga quando colocada ao lado de escritos contemporâneos de geólogos, astrônomos e físicos, embora se deva salientar mais uma vez que Davis dificilmente poderia ser ignorante de muitos dos desenvolvimentos nestes campos, visto as frequentes mençóes deles na imprensa espiritualista, incluindo no próprio jornal de Davis, The Herald of Progress. Notemos, entretanto, a referência na citação acima a "grandes fitas" de energia elétrica e a "cabos espirais" de força magnética. Aqui, novamente, a figura do fio fino - carregado de energia, ligado a um circuito maior e estendido através do espaço - fornece a estrutura arquitetônica para imaginar a operação do cosmos. $\mathrm{Na}$ visão de Davis, linhas de força não abrangem apenas o planeta Terra, elas se estendem além dele e vão até as áreas mais longínquas do Universo, na forma de

[...] rios elétricos direcionados para a Terra e para os outros planetas do nosso sistema de diferentes regióes da Terra dos Espíritos [a morada celestial das almas eternas]. [...] O método organizado de viagem entre as terras e o universo interior é por meio dos rios descritos. São as reconhecidas estradas celestes que conectam esferas e globos. (Davis, 1878, p. 93-94)

Essa rede de rios elétricos e estradas celestiais constituem o que Davis chama de uma vasta "nervo-astronomia" de forças circulantes, governada por leis eternas e etéreas de atração simpáticas. Conforme ele explica,

Os magnetismos terrestres, as eletricidades terrestres e o que mais o homem chama de 'imponderáveis' constituem o sistema nervoso desse universo físico. 
O sistema nervoso universal mantém a mesma relação com a matéria que o sistema nervoso do espírito mantém com as partes físicas do corpo [...]. Não, o mundo dos espíritos não é remoto. Nós nos movemos a cada momento na sua presença. Este próprio planeta terrestre gira em sua órbita sob a observação dos habitantes da Terra dos Espíritos [...]. Astronomicamente falando, a Terra está em um lado da vasta galáxia de sóis e planetas chamada 'Via Láctea', e diretamente através deste grande cinturão físico de estrelas, nós encontramos o repouso sublime da Terra do Sol, e isto é o receptáculo dos habitantes imortais que ascendem dos diferentes planetas que pertencem ao nosso sistema solar. Todos estes planetas têm rios celestiais que vão deles até as margens celestiais. E [assim como] cada órgão no corpo humano mantém uma relação física com o cérebro por meio dos nervos e dos rios de sangue, estes diferentes planetas no universo físico mantêm uma relação transcendental, magnética e elétrica com a Terra do Sol, a qual corresponde ao cérebro. Como a força sobe para o cérebro de um homem a partir do que ele come? Por meio da circulação. E essa circulação é regulada pela lei da atração e repulsão. Como espíritos viajam desses globos físicos até as suas casas na Terra do Sol e, o contrário, da Terra do Sol até pessoas e lugares nos planetas? Resposta: por meio da circulação. E aqui, também, a circulação-rio magnética é regulada por atração e repulsão! E assim a analogia pode ser estendida até o infinito. (Davis, 1865, p. 36-37)

\section{UMA POLÍTICA DE VISÃO}

É claro que é possível situar a teoria da "nervo-astronomia" de Davis no contexto de uma longa história de cosmologias ocultas, em que forças simpáticas parecem permear o universo, explicando coisas como correspondências astrológicas entre os movimentos de corpos planetários e humanos e as forças místicas de afinidade que permitem que até mesmo as partes mais distantes do cosmos sejam atraídas umas para as outras. Mas não percamos de vista o fato de que essas forças simpatizantes são representadas aqui através dos idiomas visual e discursivo dos sistemas nervosos, redes telegráficas e outras mídias demonstradas na figura do circuito elétrico. Ao localizar a 
simpatia dentro dessa ordem nervo-astronômica, Davis não apenas atualiza o tropo arcaico da Unio Mystica como também reconstitui suas próprias condiçôes de possibilidade. A alma interior e os céus superiores estavam agora ligados às amarras da tecnociência transatlântica do século XIX; simpatia entre almas agora era algo que poderia ser atingido - se não, diretamente, analogicamente - através da arquitetura medial das redes elétricas e através dos efeitos observáveis das forças eletromagnéticas nos territórios e modalidades de indústria, tanto grandes quanto pequenas. Não é muito surpreendente, então, que Davis tenha proposto um cabo magnético, dentre todos os instrumentos, a fim de ajudar os pesquisadores de conhecimento espiritualistas a navegar no cosmos nervo-astronômico e, assim, estabelecer conexôes comunicativas confiáveis com o mundo espiritual.

Eu não quero sugerir aqui que, simplesmente porque eles apropriaram-se dos idiomas visual e discursivo do circuito elétrico, os espiritualistas como Davis de alguma forma juntaram-se à comunidade científica da época deles. Uma coisa é invocar metáforas eletromagnéticas nos escritos de alguém, mas outra bem diferente é tentar elaborar resultados sobre as propriedades de tais forças com base na observaçáo controlada, entre outros protocolos de prática experimental que servem para distinguir o conhecimento científico. $\mathrm{Na}$ verdade, a cosmologia espiritualista e a prática de séance parecem encaixar melhor na história de demonstraçóes públicas da ciência do que na sua história formal de experimentação e teorização. Provavelmente tanto Davis quanto seus leitores tinham no mínimo um conhecimento de segunda mão, se não uma experiência direta, de exemplos do que, no século XIX, já havia se tornado uma tradição vulnerável entre apresentadores elétricos itinerantes de convidar a plateia a dar as mãos e experimentar choques simultâneos em um circuito humano. A cultura popular de demonstração elétrica e de experiências amplamente discutidas de choque eletrostático eram certamente tão (ou mais) importantes para a geração de ideias espiritualistas sobre corpo, alma e espírito quanto os experimentos, debates e outras formas de troca intelectual que ocorriam na comunidade científica profissional. Nessa mesma linha de raciocínio, notemos também que através de suas infinitas referências 
aos "fluidos" e às "chamas", Davis usava uma linguagem mais reminiscente do discurso científico profissional do século XVIII e não do século XIX, fazendo sua explicação do sistema nervoso espiritual soar anacrônica, se não vulgar. Até mesmo a construção de um dispositivo como o cabo magnético dificilmente pode ser usada para competir com a complexidade mecânica e operacional dos sistemas de telégrafo reais, cujos projetos eram baseados em conhecimento especializado de circuito elétrico e cujo funcionamento dependia da coordenação de processos complexos de produção de metal e geração de energia, sem mencionar as somas consideráveis de capital financeiro necessárias para alimentar essa indústria em expansão. Então, não é tentador tratar o cabo magnético, junto com o estoque familiar de tecnologias espiritualistas, como tabuleiros (de ouija), quadros negros e trompetes falantes, como pouco mais do que brinquedos amadores ou réplicas grosseiras de instrumentos modernos da ciência e da indústria? ${ }^{41}$ Não é igualmente tentador tratar a cosmologia espiritualista como uma tentativa fantasiosa de imitar a fala científica "real" sobre a estrutura fundamental do universo e do comportamento dos seus vários moradores?

As respostas afirmativas a essas questóes presumem a legitimidade de uma divisão entre, por um lado, fatos naturais, assegurados por testemunhas cuja credibilidade é afirmada por uma comunidade de especialistas científicos reconhecidos e, por outro, as arenas populares de mágica, espetáculo e especulação metafísica (na qual "fatos" acabam sendo meramente representaçóes ideológicas, passíveis de serem atribuídas a condiçóes sociais e culturais de seus crentes). Mas essa distinção entre questóes de fato e questóes de crença é em si um produto histórico do que Bruno Latour (1993) celebremente chamou de "A Constituição Moderna": uma disposição paradoxal de ciências

${ }^{41}$ Steven Connor, por exemplo, comentou sobre "o anacronismo peculiarmente persistente das tecnologias emprestadas pelas séance," identificando dispositivos como trompetes em levitação e diodos de bigodes de gato como "tecnologias imaginárias [que] estão sempre um pouco fora de moda, levemente desajeitadas e toscas"; Connor (1999, p. 223), Machine in the Ghost.

Debates do NER, Porto Alegre, ANo i 9, N. 35, P. 293-346, JAN./JUl. 20 i 9 
e políticas, fatos e valores e conhecimento e poder, que são todos preconizados para serem epistemológica e ontologicamente distintos um do outro, ao mesmo tempo em que se tornaram interdependentes de formas novas e mais profundas através da proliferação das representações tecnologicamente mediadas e açóes coordenadas entre humanos e não humanos. Se, como Latour argumenta, não era, e talvez nunca seja, possível desarticular questôes relativas à sociedade e à natureza de cada um, muito menos separá-las de questóes mais fundamentais sobre a ética, a origem, a causalidade ou o futuro que às vezes designamos como as preocupaçóes "máximas" da religiáo, parece que a caracterização das cosmologias espirituais, dos procedimentos técnicos e dos instrumentos de comunicação espiritual do século XIX como "meramente popular" não é mais do que o decreto retórico da comunidade científica profissional.

As coisas não eram tão evidentes no tempo de Davis. No decorrer da sua carreira, a maioria das profissóes científicas, médicas e da engenharia estavam apenas começando a tomar uma forma institucional. Ao longo do século XIX, por exemplo, os termos eletricista e engenheiro elétrico eram categorias marcadamente permeáveis, designando um bando de autodidatas como mecânicos, designer de motores, operadores de telégrafos e outras partes interessadas profissionalmente treinados. Foi apenas no final do século que profissionais elétricos fizeram um esforço contínuo para distinguir a sua legitimidade como especialistas contra o analfabetismo tecnológico dos "de fora” ${ }^{42} \mathrm{O}$ mesmo tem sido observado na história de outros ramos da ciência, medicina e engenharia, nos quais os organismos profissionais emergentes buscavam exercer uma autoridade recém-conquistada, criticando o charlatanismo, a mágica, os delírios coletivos e as mentes supersticiosas. Mas nenhum pretendente à ortodoxia científica jamais exerceu um monopólio

42 Como Carolyn Marvin notou, engenheiros elétricos estavam entre os últimos profissionais da engenharia a consolidar a sua legitimidade na forma de uma associação profissional: o Instituto Americano de Engenheiros Eletricistas, criado em 1884; ver Marvin (1988, p. 10-15). 
total sobre o terreno anárquico de terapias médicas, invenções amadoras e descriçôes da natureza ou do mundo que se encontra além. $\mathrm{Na}$ época em que Davis revelou seus projetos de um cabo magnético, o negócio do experimento científico, demonstração, publicação e discussão era na verdade ocupado por diversas autoridades, muitas vezes autonomeadas, que estavam ansiosas para tirar vantagem dos horizontes interpretativos flexíveis e ainda contestáveis, dentro dos quais o conhecimento do universo deveria estar localizado. ${ }^{43}$

O status incipiente das profissóes científicas e da engenheira no século XIX foi acompanhado por uma ampla falta de consenso no que diz respeito à interpretação de dados científicos, bem como de padróes divergentes para definir e medir o sucesso na concepção e implementação de novas tecnologias. Pode-se considerar, a esse respeito, a longa história de frustração entre os fisiologistas de que o sistema nervoso permanecia impenetravelmente misterioso. Em 1764, Robert Whytt concluiu que "[...] a pequenez extrema dos tubos nervosos e a sutileza de seu fluido nos faz completamente ignorantes de sua natureza e propriedades peculiares." (Whytt, 1765, p. 2 apud Salibury; Shail, 2010) Em 1812, Thomas Trotter reclamou que as "[...] dissecaçóes não encaminharam nosso conhecimento" (Trotter, 1812, p. 213 apud Salisbury; Shail, 2010) sobre como exatamente o sistema nervoso opera. Helmholtz, por sua vez, lamentou que os fisiologistas tivessem "[...] sido até agora incapazes de definir" se “[...] o verdadeiro processo de irritação em nervos individuais pode ser exatamente sempre o mesmo, assim como a corrente elétrica nos fios do telégrafo continua sendo a mesma apesar dos vários tipos de efeitos que ela produz nas suas extremidades." (Helmholtz, 1877, p. 149). Em vez de interpretar tais comentários retroativamente a partir da perspectiva de um conjunto "mais completo" e "purificado" de conhecimento neurofisiológico que nós temos hoje em dia, poderíamos nos

43 Sobre o editorial de ciência popular do século XIX, ver Geoffrey Cantor, Gowan Dawson, Richard Noakes, Sally Shuttleworth, e Jonathan R. Topham, (2004); Susan Sheets-Pyenson (1985, p. 549-72).

Debates do NER, Porto Alegre, ANo i 9, N. 35, P. 293-346, JAN./JUl. 20 i 9 
beneficiar de uma maior atenção às formas que Whytt, Trotter, Helmholtz e muitos outros cientistas, inconscientemente ou não, estavam colocando em relevo mais questóes não resolvidas sobre o que conta como um instrumento útil ou um procedimento técnico na geração de conhecimento confiável. Alguém poderia sugerir que talvez o sistema nervoso fornecesse uma base para debates interpretativos acalorados justamente porque seus melhores acabamentos encontram-se além do ponto de fuga do microscópio do século XIX, quando as especulações eram muitas e era impossível distinguir a física da metafísica. ${ }^{44}$

O que se pode dizer sobre os fundamentos instáveis da neurologia do século XIX poderia facilmente se dizer sobre os sistemas de telégrafo, que eram cercados por consideráveis dificuldades técnicas e operacionais. As redes eram suscetíveis à falta de energia, os climas eram inóspitos e os cabos eram frequentemente cortados (o caso mais famoso foi o do cabo do telégrafo transatlântico de 1856, que conectou a Inglaterra e os Estados Unidos pela primeira vez, que durou apenas vinte e três dias). Não havia muito acordo entre as naçóes sobre como estabelecer padróes técnicos uniformes para a comunicação telegráfica, um problema que foi apenas parcialmente corrigido com a formação da União Internacional de Telégrafos, em 1865. De fato, na época dos escritos de Davis, nós estávamos longe de ver um mundo envolto por um círculo de sistemas telegráficos confiáveis e perfeitamente interconectados; "a rede" era mais uma fantasia utópica do que uma realidade vivida.

Dessa forma, parece que no século XIX o que conectou mais dramaticamente o gigantismo do espaço mundial e o microcosmo de comunicaçóes

44 Também não era o caso de cientistas "profissionais" desfrutarem de acesso exclusivo a tais instrumentos, como é evidente a partir da longa história do consumo doméstico de aparatos em razão da "ciência de salão." Considere a esse respeito o papel dos microscópios na cultura popular norte-americana a partir da década de 1850; ver John Harley Warner, (1982, p. 7-33). No outro extremo do espectro visível, para um conjunto de discussốes ecléticas e instigantes do papel dos telescópios e da astronomia popular no mundo atlântico do século XIX, ver David Aubin, Charlotte Bigg, and H. Otto Sibum, eds., (2010).

Debates do NER, Porto Alegre, Ano i 9, N. 35, P. 293-346, Jan./Jul. 20 i 9 
corporais foram questôes significativamente não resolvidas sobre as forças que animavam o universo: forças que continuavam difíceis de localizar ou de aproveitar, e muito menos de explicar totalmente. O espiritualismo e a ciência profissional encontraram-se, assim, em uma zona indeterminada de complementaridade, competição e troca. Localizados nessa zona de contato, espiritualistas e cientistas profissionais têm uma suposição em comum incorporada na promessa da observação escópica: ver adequadamente é saber a ordem verdadeira das coisas. E, no entanto, para ambos, algumas das coisas mais fundamentais a serem conhecidas são de fato invisíveis para os sentidos humanos puros, e é somente em suas mediações técnicas que elas tornam-se visíveis. Em contraste com o fundo escuro de um imenso universo de coisas ocultas à visão natural, as técnicas espiritualistas para registrar a presença espiritual e os instrumentos científicos para registrar os efeitos da eletricidade foram moldados dessa forma pelos mesmos princípios de uma invisibilidade constitutiva que ia redefinindo o exato sentido da visão e da percepção sensorial, tornando atos visíveis e fatos em dados construídos e calculados, deslocando as "coordenadas naturais" do olho humano e estigmatizando toda experiência visível com a mancha da temporalidade.

Davis estava profundamente ciente do nível em que os cientistas profissionais de sua época estavam ligados a essa demanda impossível e insatisfatória por visibilidade "não mediada", e usou as limitaçôes epistemológicas da observação científica como um grande efeito retórico. Se os cientistas não podem ver o que os espiritualistas sabem, isso é uma consequência direta da inadequação tecnológica dos instrumentos que mediam a representação científica. Davis escreveu sobre isso:

Pode parecer para a sua imaginação que o mundo espiritual está muito longe - que deve ser uma existência vasta e remota, já que os astrônomos não olharam para ele. Mas creio eu que os astrônomos, com seus instrumentos físicos, reconhecerão, em um dos felizes dias futuros, a Terra do Verão, e eu acredito ainda que eles verão paisagens e cenas físicas de forma mais clara do 
que naquelas vagas imagens que são agora reveladas através de telescópios, como as existentes da lua e de diferentes estrelas (Davis, 1987, p. 36).

Assim como os astrônomos ainda não conseguem localizar ou registrar visualmente a distante morada celestial das almas que já partiram, os fisiologistas ainda não avistaram a profunda força animadora do espírito dentro do corpo, que "[...] se encontra retido nos seus menores nervos, nos seus mais finos pontos de vida e sensaçóes.” Ele continua:

Os tecidos [do corpo humano] são construídos fora da vida invisível do sistema nervoso. Mas o que compóe o sistema nervoso? Esses médicos físicos podem identificar os nervos. Mas há um determinado princípio oculto dentro dos nervos, dentro da eletricidade e vida dinâmica dos nervos, dentro do magnetismo suave que cobre a eletricidade fina - algo dentro de tudo em você que é humano e interior - um princípio de recuperaçáo conhecido apenas pelo poder que você sente.

Em um outro texto, Davis aprofunda-se nessa interação de observação escópica e força invisível através de uma "examinação clarividente" que ele conduziu no seu próprio nervo pneumogástrico (também conhecido como o nervo vago, um dos nervos cranianos centrais, espalhados para a faringe, para o esôfago, para a laringe, para os pulmóes, para o coraçáo, para o estômago, para o fígado, para o baço e para a maior parte das vísceras abdominais), um objeto de atenção contínua entre anatomistas daquele tempo. Não necessitando confiar nas capacidades limitadas de representaçáo dos microscópios, Davis relata como ele:

[...] traçou as terminações do nervo para a cavidade intestinal, sobre os tecidos musculares dos quais nós alegamos que sua influência motriz era fácil e livremente exercida [...]. Visto com os olhos de chumbo do materialismo e estudado do ponto de vista totalmente fisiológico, o corpo não apresenta nada "horrível ou maravilhoso". Entretanto, uma vez abertos os olhos espirituais - fixem seus poderes analíticos sobre a estrutura anatômica do sistema nervoso - e as maravilhas de um universo são instantaneamente reveladas para o seu entendimento. Discos nos órgãos, tecidos nos músculos, fibras nos 
nervos, glóbulos no sangue, movimento na vida, sensação no movimento e uma infinidade de belos processos acontecendo nos diversos departamentos do templo simultaneamente - todos impressionam o observador espiritual com verdades sublimes e indizíveis e com gratidão além de todas as barreiras da expressão. (Davis, 1860, p. 4)

Da mesma forma que os "olhos espirituais" do clarividente são aqui mostrados como instrumentos confiáveis para a representação visual das energias espirituais, o cabo magnético apresenta a si mesmo como uma ferramenta confiável de comunicação espiritual. Alguém pode bem imaginar que a eficácia do cabo de Davis teria sido negado em um primeiro momento por uma determinação científica que se recusou a considerar a possibilidade teórica de forças espirituais, apesar do fato (ou talvez justamente por causa dele) de, naquele exato momento, espiritualistas como Davis estarem procurando a sua própria credibilidade explicando o funcionamento do cabo magnético em termos de comportamento observável de sinais e circuitos elétricos. Mas em que bases podemos dizer qual dos interlocutores nesse debate obteviveram sucesso ao fornecer uma explicação mais "verdadeira" das forças invisíveis que governam o cosmos? Quem foi autorizado a determinar a produção de conhecimento confiável sobre a disponibilidade de forças invisíveis a modos de representação e de ação mediados tecnologicamente? Assumir que o cabo magnético era meramente uma invenção da imaginação espiritualista é se colocar ao lado dos caluniadores de Davis, tanto da época quanto os de hoje em dia, em nome de uma prática tecnocientífica purificada que se imagina como tendo sido "liberada" das amarras da metafísica - naquele exato momento, paradoxalmente, aquela tecnociência moderna tornou-se estruturada por novas formas de invisibilidade que tornam o conhecimento incompleto, se não inerentemente incompletável. Nesse caso, como em muitos outros, parece que a separação entre tecnologia e religião baseia-se em decisões políticas. Levar o cabo magnético a sério demanda que nós revisitemos a história dessa política. 
A pesquisa para este artigo foi conduzida com a ajuda do Conselho de Pesquisa em Ciências Sociais e Humanidades do Canadá. Eu gostaria de agradecer a Maria José de Abreu, Courtney Bender, Cornelius Borck, Ann Taves, Ghislain Thibault e Angela Zito por seus comentários incisivos nas versóes anteriores deste texto. Eu também fui muito beneficiado pelas perguntas e comentários dos membros da plateia nas seguintes apresentaçôes: Authorizing Inscriptions (Universidade da Califórnia - Davis, abr. 2008); Instituto de Filosofia e Ciências Humanas (Universidade Estadual do Rio de Janeiro, ago. 2008); Laboratório de Mobile Media da Universidade Concórdia (set. 2008); Invidious Distinctions and Ambiguous Attachments (Conselho de Pesquisa em Ciências Sociais, Nova Iorque, out. 2008); Centro para Religião e Mídia (Universidade de Nova Iorque, nov. 2008); e Academia Norte-Americana de Religião (Chicago, nov. 2008). Um agradecimento especial a Carly Machado, que tem colaborado comigo na pesquisa sobre o Espiritualismo do século XIX pelos últimos anos. A ideia para este artigo surgiu durante conversas com ela.

\section{REFERÊNCIAS}

ALBANESE, C. L. The Kinetic Revolution: Transformation in the Language of the Transcendentalists. New England Quarterly, v. 48, n. 3, 1975.

ALBANESE, C. L. On the Matter of Spirit: Andrew Jackson Davis and the Marriage of God and Nature. Journal of the American Academy of Religion, v. 60, n. 1, 1992.

ALBANESE, C. L. A Republic of Mind and Spirit: A Cultural History of American Metaphysical Religion. New Haven: Yale University Press, 2007. AUBIN, D.; BIGG, C.; SIBUM, H. O. (eds.). The Heavens on Earth: Observatories and Astronomy in Nineteenth-Century Science and Culture. Durham, N.C.: Duke University Press, 2010. 
BENSAUDE-VINCENT, B.; BLONDEL, C. (eds.). Science and Spectacle in the European Enlightenment. Aldershot, UK: Ashgate, 2008.

BENZ, E. The Theology of Electricity: On the Encounter and Explanation of Theology and Science in the Seventeenth and Eighteenth Centuries. Allison Park, Penn.: Pickwick, 1989.

BERTUCCI, P. Revealing Sparks: John Wesley and the Religious Utility of Electrical Healing. British Journal for the History of Science, v. 33, n. 3, 2006. BRAUDE, A. Radical Spirits: Spiritualism and Women's Rights in Nineteenth-Century America. Boston: Beacon Press, 1989.

BROOKE, J. H. Science and Religion: Some Historical Perspectives. Cambridge: Cambridge University Press, 1991.

BROWN, E. M. Neurology and Spiritualism in the 1870s. Bulletin of the History of Medicine, v. 57, n. 4, 1983.

BUESCHER, J. B. The Remarkable Life of John Murray Spear: Agitator for the Spirit Land. Notre Dame, Ind.: University of Notre Dame Press, 2006. CANTOR, G.; DAWSON, G; NOAKES, R.; SHUTTLEWORTH, S.; TOPHAM, J. R. (eds.). Science in the Nineteenth-Century Periodical: Reading the Magazine of Nature. Cambridge: Cambridge University Press, 2004.

CAREY, J. Technology and Ideology: the Case of the Telegraph. In: Communication as Culture: Essays on Media and Society. Rev. ed., [1. ed. 1989]; New York; London: Routledge, 2009.

CARROLL, B. E. Spiritualism in Antebellum America. Bloomington: Indiana University Press, 1997.

CONNOR, S. The Machine in the Ghost: Spiritualism, Technology, and the 'Direct Voice,'. In: BUSE, Peter; STOTT, Andrew (ed.). Ghosts: Deconstruction, Psychoanalysis, History. London: Macmillan, 1999. 
COOTER, R.; PUMFREY, S. Separate Spheres and Public Places: Reflections on the History of Science Popularization and Science in Popular Culture. History of Science, v. 32, n. 3, 1994.

COOTER, R. The Cultural Meaning of Popular Science: Phrenology and the Organization of Consent in Nineteenth-Century Britain. Cambridge: Cambridge University Press, 1984.

CORSI, P. (ed.). The Enchanted Loom: Chapters in the History of Neuroscience. New York; Oxford: Oxford University Press, 1991.

COX, R. S. Body and Soul: A Sympathetic History of American Spiritualism. Charlottesville: University of Virginia Press, 2003.

CRARY, J. Techniques of the Observer: on Vision and Modernity in the Nineteenth Century. Cambridge, Mass.: MIT Press, 1992.

DANIELS, G. H. The Process of Professionalization in American Science: the Emergent Period, 1820-1860. In: REINGOLD, Nathan (ed.). Science in America Since 1820. New York: Science History Publications, 1976.

DARNTON, R. Mesmerism and the End of Enlightenment in France. Cambridge, Mass.: Harvard University Press, 1968.

DAVIS, A. J. Pathological Offices of the Sympathetic Ganglia. The Herald of Progress, v. 1, n. 22, 21, jul. 1860.

DAVIS, A. J. The Soul's Telegraphic Faculty. The Herald of Progress, v. 1, n. 23, 28 jul. 1860.

DAVIS, A. J. Great Harmonia, vol. 4, The Reformer, Concerning Physiological Vices and Virtues, and the Seven Phases of Marriage, 8 ed. Boston: Colby \& Rich, 1884. DAVIS, A. J. Mental Disorders. Or, Diseases of the Brain and Nerves, Developing the Origin and Philosophy of Mania, Insanity, and Crime, With Full Directions for their Treatment and Cure. New York: American News Company, 1871. DAVIS, A. J. The Philosophy of Spiritual Intercourse, Being an Explanation of Modern Mysteries. $2^{\text {nd }}$ rev. ed. [1. ed. 1853], Boston: Colby \& Rich, 1890. 
DAVIS, A. J. The Present Age and Inner Life: Ancient and Modern Spirit Mysteries Classified and Explained. Boston: Colby \& Rich, 1886.

DAVIS, A. J. Death and the After-Life: Eight Evening Lectures on the Summer-Land. New York: A. J. Davis, 1865.

DAVIS, A. J. The Physician, Being a Philosophical Revelation of the Natural, Spiritual, and Celestial Universe. Great Harmonia, Boston, v. 1, 4 ed., 1850.

DAVIS, A. J. Views of Our Heavenly Home: a Sequel to a Stellar Key to the Summer Land. Boston: Colby \& Rich, 1878.

DELBOURGO, J. A Most Amazing Scene of Wonders: Electricity and Enlightenment in Early America. Cambridge, Mass.: Harvard University Press, 2006.

DELP, R. W. Andrew Jackson Davis: Prophet of American Spiritualism. The Journal of American History, v. 54, n. 1, 1967.

DENTON, W. The Soul of Things: Psychometric Experiments for Re-Living History. Boston, Colby \& Rich, 1863.

DIXON, T.; CANTOR, G.; PUMFREY, S. (eds.). Science and Religion: New Historical Perspectives. Cambridge: Cambridge University Press, 2010. ENNS, A. Psychic Radio: Sound Technologies, Ether Bodies, and Spiritual Vibrations. Senses and Society, v. 3, n. 2, 2008.

FARADAY, M. On the Physical Character of the Lines of Magnetic Force. In: FARADAY, M. Experimental Researches in Electricity. London: Bernard Quaritch, 1855.

FYFE, A. Science and Salvation: Evangelical Publishing in Victorian Britain. Chicago: University of Chicago Press, 2004.

HAZEN, C. J. The Village Enlightenment in America: Popular Religion and Science in the Nineteenth Century. Urbana: University of Illinois Press, 2000. 
HENSON, L.; CANTOR, G.; DAWSON, G.; NOAKES, R.; SHUTTLEWORTH, S.; TOPHAM, J. R. (eds.). Culture and Science in the Nineteenth-Century Media. Aldershot, UK: Ashgate, 2004.

HELMHOLTZ, H. On the Sensations of Tone as a Physiological Basis for the Theory of Music. Tradução de Alexander J.Elis. 2 ed., London: Longmans Green, 1885.

HUME, D. An Enquiry Concerning the Principles of Morals. London: A. Millar, 1751.

HUNT, B. J. Lines of Force, Swirls of Ether. In: Energy to Information: Representation in Science and Technology, Art and Culture. CLARKE, Bruce; HENDERSON, Linda Dalrymple (ed.). Stanford: Stanford University Press, 2002.

LAMONT, P. Spiritualism and a Mid-Victorian Crisis of Evidence. The Historical Journal, v. 47, n. 4, 2004.

LATOUR, B. We Have Never Been Modern. Cambridge, Mass.: Harvard University Press, 1993.

LEE, E. A Treatise on Some Nervous Disorders: Being Chiefly Intended to Illustrate those Varieties which Stimulate Structural Disease. London: Burgess Hill, 1833.

LINDSAY, W. L. Mind in Disease. In: LINDSAY, W. L. Mind in the Lower Animals. London: Kegan Paul, v. 2, 1879.

MARVIN, C. When Old Technologies Were New: Thinking About Electrical Communication in the Late Nineteenth Century. New York; Oxford: Oxford University Press, 1988.

MCGARRY, M. Ghosts of Futures Past: Spiritualism and the Cultural Politics of Nineteenth-Century America. Berkeley: University of California Press, 2008. MORUS, I. R. Frankenstein's Children: Electricity, Exhibition, and Experiment in Early Nineteenth-Century London. Princeton: Princeton University Press, 1998. 
MORUS, I. R. 'The Nervous System of Britain': Space, Time, and the Electric Telegraph in the Victorian Age. British Journal for the History of Science, v. 33, n. 4, 2000.

MORUS, I. R. Radicals, Romantics and Electrical Showmen: Placing Galvanism at the End of the English Enlightenment. Notes and Records of the Royal Society, v. 63, n. 3, 2009.

MÜLLER, J. Elements of Physiology. Traduçáo de William Bally. 2 ed. Philadelphia: Lean: Blanchard, 1843.

NADIS, F. Wonder Shows: Performing Science, Magic, and Religion in America. New Brunswick, N.J.: Rutgers University Press, 2005.

NOAKES, R. J. Telegraphy is an occult art: Cromwell Fleetwood Varley and the Diffusion of Electricity to the Other World. British Journal for the History of Science, v. 32, n. 4, 1999.

O'REILLY, J. The Anatomy and Physiology of the Placenta: the Connection of the Nervous Centres of Animal and Organic Life. New York: Hall Clayton, 1860.

OTIS, L. Networking: Communicating with Bodies and Machines in the Nineteenth Century. Ann Arbor: University of Michigan Press, 2001.

OWEN, A. The Darkened Room: Women, Power, and Spiritualism in Late Victorian England. Chicago: University of Chicago Press, 1989.

PALFREMAN, J. Between Skepticism and Credulity: a Study of Victorian Scientific Attitudes to Modern Spiritualism. In: WALLIS, Roy (ed.). On the Margins of Science: The Social Construction of Rejected Knowledge. Keele, UK: University of Keele, 1979.

PELS, P. Spirits and Modernity: Alfred Wallace, Edward Tylor, and the Visual Politics of Facts. In: MEYER, Birgit; PELS, Peter (ed.). Magic and Modernity: Interfaces of Revelation and Concealment. Stanford: Stanford University Press, 2003. 
PERA, M. The Ambiguous Frog: the Galvani-Volta Controversy on Animal Electricity. Princeton: Princeton University Press, 1992.

ROUSSEAU, G. S. Nervous Acts: Essays on Literature, Culture and Sensibility. Houndsmills, UK: Palgrave-Macmillan, 2004.

SALISBURY, L.; SHAIL, A. Introduction. In: Neurology and Modernity: a Cultural History of Nervous Systems, 1800-1950, (ed.). SALISBURY, Laura; SHAIL, Andrew. London: Palgrave-Macmillan, 2010.

SCHAFFER, S. Natural Philosophy and Public Spectacle in the Eighteenth Century. History of Science, n. 21, mar. 1983.

SCHAFFER, S. Scientific Discoveries and the End of Natural Philosophy. Social Studies of Science, v. 16, 1986.

SCHAFFER, S. The Consuming Flame: Electrical Showmen and Tory Mystics in the World of Goods. In: BREWER, John; PORTER, Roy (ed.). Consumption and the World of Goods. New York: Routledge, 1993.

SCONCE, J. Haunted Media: Electronic Presence from Telegraphy to Television. Durham, N.C.: Duke University Press, 2000.

SCOTT, D. M. The Popular Lecture and the Creation of a Public in Mid-Nineteenth Century America. Journal of American History, v. 66, n. 4, 1980.

SHEETS-PYENSON, S. Popular Science Periodicals in Paris and London: the Emergence of a Low Scientific Culture, 1820-1875. Annals of Science, v. $42,1985$.

SHEPHERD, G. M. Foundations of the Neuron Doctrine. Oxford: Oxford University Press, 1991.

SMITH, A. The Theory of Moral Sentiments. Cambridge: Cambridge University Press, 2002. 
SOLLORS, W. Dr. Benjamin Franklin's Celestial Telegraph, or Indian Blessings to Gas-lit American Drawing Rooms. Social Science Information, v. 22, n. 6, 1983.

STERNE, J. The Audible Past: Cultural Origins of Sound Reproduction. Durham, N.C.: Duke University Press, 2003.

STOLOW, J. Salvation by Electricity. In: VRIES, Hent de (ed.). Religion: Beyond a Concept. New York: Fordham University Press, 2008.

TURNER, F. M. The Victorian Conflict between Science and Religion: a Professional Dimension. Isis, v. 69, 1978.

WADGE, E. The Scientific Spirit and the Spiritualist Scientist: Moving in the Right Circles. The Victorian Review, v. 26, n. 1, 2000.

WARNER, J. H. 'Exploring the Inner Labyrinths of Creation': Popular Microscopy in Nineteenth-Century America. Journal of the History of Medicine and Allied Sciences, v. 37, n. 1, 1982.

WEINSTEIN, S. Technologies of Vision: Spiritualism and Science in Nineteenth-Century America. In: WEINSTOCK, Jeffrey Andrew (ed.). Spectral America: Phantoms and the National Imagination. Madison: University of Wisconsin Press, 2004.

WEISZ, G. The Emergence of Medical Specialization in the Nineteenth Century. Bulletin of the History of Medicine, v. 77, n. 3, 2003.

ZOCHERT, D. Science and the Common Man in Ante-Bellum America. In: REINGOLD, Nathan (ed.). Science in America Since 1820. New York: Science History Publications, 1976.

Recebido em: 27/02/2018

Aprovado em: 31/03/2018 